\title{
Carbon Formation and Metal Dusting in Advanced Coal Gasification Processes
}

\author{
RECEIVED \\ MAR 031997 \\ OSTI
}

\author{
J.H. DeVan \\ P. F. Tortorelli \\ R. R. Judkins \\ I. G. Wright
}

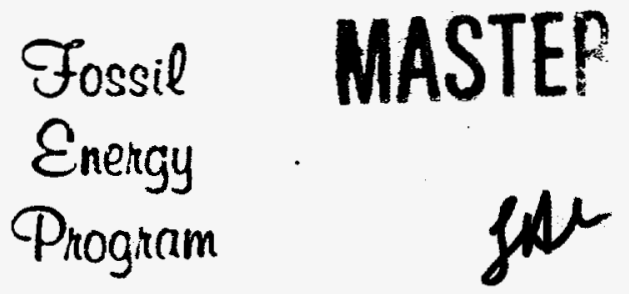


This report has been reproduced directly from the best available copy.

Available to DOE and DOE contractors from the Office of Scientific and Technical Information, P. O. Box 62, Oak Ridge, TN 37831: prices available from (423) 576-8401. FTS 626-8401.

Available to the public from the National Technical Information Service, U.S. Department of Commerce. 5285 Port Royal Road. Springfield. VA 22161.

This report was prepared as an account of work sponsored by an agency of the United States Government. Neither the United States Government nor any agency thereof, nor any of their employees, makes any warranty, express or implied. or assumes any legal liability or responsibility for the accuracy, completeness. or usefulness of any information, apparatus, product, or process disclosed, or represents that its use would not infringe privately owned rights. Reference herein to any specific commercial product. process, or service by trade name. trademark, manufacturer, or otherwise, does not necessarily constitute or imply its endorsement, recommendation, or favoring by the United States Government or any agency thereof. The views and opinions of authors expressed herein do not necessarily state or reflect those of the United States Government of any agency thereof. 


\section{DISCLAIMER}

Portions of this document may be illegible electronic image products. Images are produced from the best available original document. 
Metals and Ceramics Division

\title{
CARBON FORMATION AND METAL DUSTING IN ADVANCED COAL GASIFICATION PROCESSES
}

\author{
J. H. DeVan \\ P. F. Tortorelli \\ R. R. Judkins \\ I. G. Wright
}

Date Published-February 1997

\author{
Prepared by the \\ OAK RIDGE NATIONAL LABORATORY \\ Oak Ridge, Tennessee 37831-6285 \\ managed by \\ LOCKHEED MARTIN ENERGY RESEARCH CORP. \\ for the \\ U.S. DEPARTMENT OF ENERGY \\ under contract DE-AC05-96OR22464
}




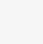




\section{CONTENTS}

LIST OF FIGURES $\ldots \ldots \ldots \ldots \ldots \ldots \ldots \ldots \ldots \ldots \ldots \ldots \ldots \ldots \ldots \ldots \ldots \ldots \ldots \ldots \ldots \ldots \ldots$

LIST OF TABLES $\ldots \ldots \ldots \ldots \ldots \ldots \ldots \ldots \ldots \ldots \ldots \ldots \ldots \ldots \ldots \ldots \ldots \ldots \ldots \ldots \ldots$

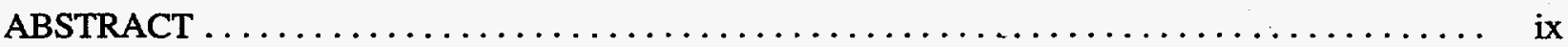

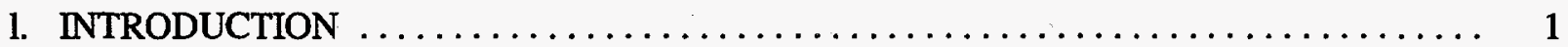

2. THERMOCHEMICAL CALCULATIONS FOR REPRESENTATIVE

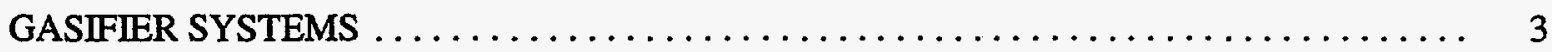

3. CONDITIONS THAT INFLUENCE KINETICS OF CARBON DEPOSITION $\ldots \ldots \ldots \ldots 11$

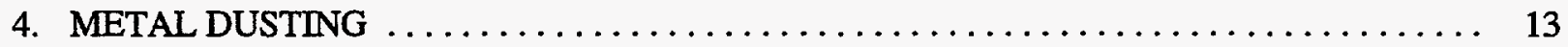

5. INFLUENCE OF SYSTEM OPERATING PARAMETERS ON CARBON DEPOSITION AND METAL DUSTING $\ldots \ldots \ldots \ldots \ldots \ldots \ldots \ldots \ldots \ldots \ldots \ldots \ldots$

6. MATERIAL SELECTION CONSIDERATIONS FOR HOT-GAS CLEANUP SECTIONS OF COAL GASIFICATION SYSTEMS $\ldots \ldots \ldots \ldots \ldots \ldots \ldots \ldots \ldots \ldots \ldots .21$

7. RECOMMENDATIONSं FOR FURTHER EVALUATION OF POSSIBLE DEGRADATION MODES $\ldots \ldots \ldots \ldots \ldots \ldots \ldots \ldots \ldots \ldots \ldots \ldots \ldots \ldots \ldots \ldots$

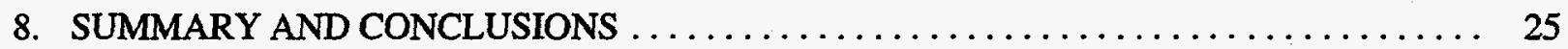

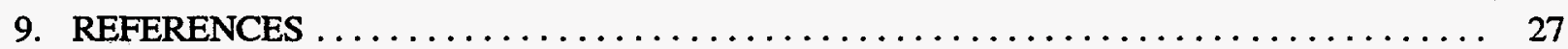

Appendix A. INDICATIONS OF METAL DUSTING IN OPERATING COAL GASIFICATION PLANTS $\ldots \ldots \ldots \ldots \ldots \ldots \ldots \ldots \ldots \ldots \ldots \ldots \ldots \ldots \ldots \ldots \ldots$

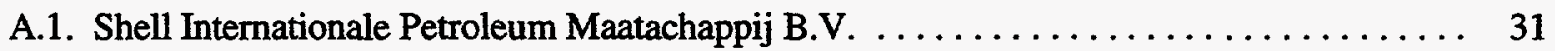

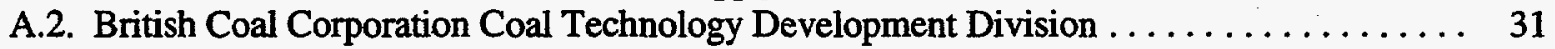

A.3. British Gas plc . . . . . . . . . . . . . . 31 


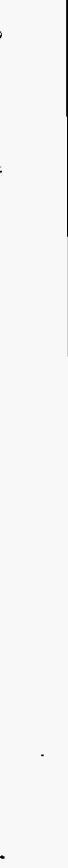




\section{LIST OF FIGURES}

Figure

1 SOLGASMIX-calculated equilibrium levels of solid carbon showing temperature at which unit $\mathrm{a}_{c}$ is achieved for various air-blown gasifiers

2. SOLGASMIX-calculated equilibrium levels of solid carbon showing temperature at which unit $a_{c}$ is achieved for various air-blown gasifiers under the assumption of no methane formation

3 SOLGASMIX-calculated equilibrium levels of solid carbon showing temperature at which unit $\mathrm{a}_{\mathrm{c}}$ is achieved for various oxygenblown gasifiers

4 SOLGASMIX-calculated equilibrium levels of solid carbon showing temperature at which unit $\mathrm{a}_{\mathrm{c}}$ is achieved for various oxygen-blown gasifiers under the assumption of no methane formation

5 Schematic representation of the steps involved in degradation by metal dusting

6 Schematic representation of reactivity vs temperature for pure iron, nickel, and cobalt in 1 atm of pure $\mathrm{CO}$

7 Deposits on $\mathrm{Fe}-\mathrm{Ni}$ alloys after $24 \mathrm{~h}$ of exposure in $\mathrm{CO}-\mathrm{H}_{2}-\mathrm{H}_{2} \mathrm{O}$ at 0.1 bar $\mathrm{CO}$ and $650^{\circ} \mathrm{C}$ as measured by mass gain as a function of nickel concentration 


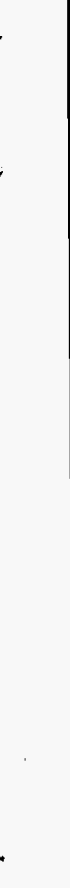




\section{LIST OF TABLES}

Table

Page

1 Gas composition and pressures of reference air-blown gasifiers $\ldots \ldots \ldots \ldots \ldots \ldots \ldots \ldots$

2 Gas compositions and pressures of reference oxygen-blown gasifiers $\ldots \ldots \ldots \ldots \ldots$

3 Predominant solid-state phases of iron when exposed to reference

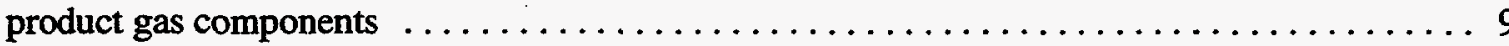




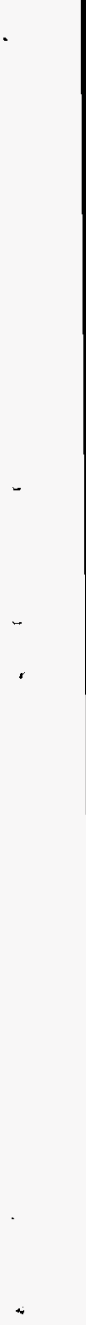




\begin{abstract}
The product gases generated by coal gasification systems contain high concentrations of $\mathrm{CO}$ and, characteristically, have relatively high carbon activities. Accordingly, carbon deposition and metal dusting can potentially degrade the operation of such gasifier systems. Therefore, the product gas compositions of eight representative gasifier systems were examined with respect to the carbon activity of the gases at temperatures ranging from 480 to $1090^{\circ} \mathrm{C}\left(900\right.$ to $2000^{\circ} \mathrm{F}$ ). The composition of the product gas is such that high carbon activities are guaranteed when the gas is cooled after exiting the gasifier. Assuming that all of the gas components are in thermodynamic equilibrium, calculations show that carbon activities greater than unity would result at temperatures below 800 to $870^{\circ} \mathrm{C}\left(1470\right.$ to $\left.1600^{\circ} \mathrm{F}\right)$ in the case of air-blown gasifiers and at considerably higher temperatures in the case of oxygen-blown gasifiers containing greater than $54 \mathrm{vol} \% \mathrm{CO}$.

Phase stability calculations indicated that $\mathrm{Fe}_{3} \mathrm{C}$ is stable only under very limited thermodynamic conditions and with certain kinetic assumptions and that $\mathrm{FeO}$ and $\mathrm{Fe}_{0.877} \mathrm{~S}$ tend to form instead of the carbide. As formation of $\mathrm{Fe}_{3} \mathrm{C}$ is a necessary step in the metal dusting of steels, there are numerous gasifier environments where this type of carbon-related degradation will not occur, particularly under conditions associated with higher oxygen and sulfur activities. These calculations also indicated that the removal of $\mathrm{H}_{2} \mathrm{~S}$ by a hot-gas cleanup system may have less effect on the formation of $\mathrm{Fe}_{3} \mathrm{C}$ in air-blown gasifier environments, where the iron oxide phase can exist and is unaffected by the removal of sulfur, than in oxygen-blown systems, where iron sulfide provides the only potential barrier to $\mathrm{Fe}_{3} \mathrm{C}$ formation. However, overall, the adoption of hot-gas desulfurization strategies will probably increase carbon-related degradation, since $\mathrm{H}_{2} \mathrm{~S}$ is removed in a temperature regime where carbon deposition and metal dusting are possible.

Use of carbon- and/or low-alloy steels dictates that the process gas composition be such that $\mathrm{Fe}_{3} \mathrm{C}$ cannot form if the potential for metal dusting is to be eliminated. Alternatively, process modifications could include the reintroduction of hydrogen sulfide (to poison the carbon deposition reaction or to form iron sulfide at the expense of $\left.\mathrm{Fe}_{3} \mathrm{C}\right)$, cooling the gas to perhaps as low as $400^{\circ} \mathrm{C}\left(750^{\circ} \mathrm{F}\right)$, and/or steam injection. If higher-alloy steels (those that will form and maintain a protective chromia film on the surface) are used, a hydrogen sulfide-free gas (or a gas with very low hydrogen sulfide content at higher temperatures) may be processed without concern about carbon deposition and metal dusting.

It was concluded that testing, preferably under prototypical çoal gasification conditions, will be needed to experimentally validate the thermodynamic calculations and assumptions about kinetic limitations that are key to developing a predictive capability with respect to carbon formation and metal dusting.
\end{abstract}




\section{INTRODUCTION}

The product gas resulting from the partial oxidation of carboniferous materials in a gasifier consists predominantly of $\mathrm{CO}, \mathrm{CO}_{2}, \mathrm{H}_{2}, \mathrm{H}_{2} \mathrm{O}, \mathrm{CH}_{4}$, and, for air-blown units, $\mathrm{N}_{2}$, in various proportions at temperatures ranging from about 400 to $1000^{\circ} \mathrm{C}\left(750\right.$ to $\left.1830^{\circ} \mathrm{F}\right)$. Depending on the source of the fuel, smaller concentrations of $\mathrm{H}_{2} \mathrm{~S}, \mathrm{COS}$, and $\mathrm{NH}_{3}$ can also be present. The gas phase is typically characterized by high carbon and sulfur, but low oxygen, activities, and, consequently, severe degradation of the structural and functional materials used in the gasifier can occur. Therefore, there are numerous concerns about materials performance in coal gasification systems, particularly at the present time, when demonstration-scale projects are in or nearing construction and operation phases. This report focuses on a subset of materials degradation phenomena resulting from carbon formation and carburization processes, which are related to potential operating problems in certain gasification components and subsystems. More specifically, the report (1) summarizes the current state of knowledge regarding carbon deposition and a carbon-related degradation phenomenon known as metal dusting as they affect the long-term operation of the gas cleanup equipment downstream of the gasifier and (2) addresses possible means to mitigate the degradation processes. These effects are primarily associated with filtering and cooling coal-derived fuel gases at temperatures ranging from the gasifier exit temperature to as low as $400^{\circ} \mathrm{C}\left(750^{\circ} \mathrm{F}\right)$. However, some of the considerations discussed in the present report will be sufficiently general to cover conditions relevant to other parts of gasification systems.

There are several possible materials/systems degradation modes that result from gasification environments with appreciable carbon activities. These processes, which are not necessarily mutually exclusive, include carbon deposition, carburization, metal dusting, and $\mathrm{CO}$ disintegration of refractories. Each of these phenomena will be briefly described so as to define the particular uses of the terms in this report. There is a lack of unanimity in the literature regarding such definitions, and care must be used in evaluating reported observations that use these terms.

Carbon formation on solid surfaces occurs by deposition from gases where carbon activities $\left(\mathrm{a}_{\mathrm{c}} \mathrm{s}\right)$ exceed unity. The presence of a carbon layer can directly affect gasifier performance by restricting gas flow, particularly in the hot-gas filter, creating debris that may be deposited elsewhere in the system or that may cause erosive damage of downstream components, and/or changing the catalytic activity of surfaces. Several sources of information exist on carbon deposition that are relevant to the operation of gasifiers. Blast furnaces, catalytic processes such as Fischer-Tropsch syntheses for hydrocarbon production, and gas-cooled power reactors have all experienced detrimental effects as a result of carbon formation via the decomposition of $\mathrm{CO}$ (Boudouard reaction). In these systems, the principal problem is simply the disruption of normal operations caused by the formation and deposition of carbon.

There are also material degradation effects resulting from the formation of carbon layers. A principal one is the phenomenon of metal dusting, ${ }^{1-4}$ which requires a high carbon activity $\left(a_{c} \gg 1\right)$ and proceeds by a combination of mechanisms. The high carbon activity obtained in the gas phase provides the driving forces for the formation of $\mathrm{M}_{3} \mathrm{C}$ carbides and deposition of carbon. The carbon deposition reduces the $\mathrm{a}_{\mathrm{c}}$ at the metal surface to unity, and the carbides (stable only when $a_{c}>1$ ) then decompose to form metal particles and filamentous carbon in the form of a dust that can be carried away by the flowing gas. Pits and holes on affected surfaces can be observed in addition to general metal wastage. The degradation is typically observed at intermediate temperatures of about 400 to $900^{\circ} \mathrm{C}\left(750\right.$ to $\left.1650^{\circ} \mathrm{F}\right)$. The steps involved in metal dusting are more fully described in Sect. 4. This phenomenon can be distinguished from carburization normally seen with high-temperature alloys. Carburization results in the formation of stable carbides on and within the solid exposed to a carbon-containing environment (even at $\mathrm{a}_{\mathrm{c}}<1$ ). The formation of such carbides (normally $\mathrm{M}_{7} \mathrm{C}_{3}$, $\mathrm{M}_{23} \mathrm{C}_{6}$, or $\mathrm{MC}$, where $\mathrm{M}=\mathrm{Cr}, \mathrm{Mo}$, or $\mathrm{Fe}$ ) can lead to loss of ductility, mechanical disintegration, and loss of oxidation resistance (see, for example, refs. 5-7). In some cases, this form of carburization has been reported to precede metal dusting, ${ }^{3}$ but it is distinct from the actual degradation mechanism associated with the latter phenomenon. There are cases where such a distinction has not been made, and "metal dusting" has been used 
to refer to other carburization effects. The formation of filamentous carbon by disproportionation of carbon monoxide actually exploits the process of metal dusting. ${ }^{8}$

Deterioration of refractories used in coal gasification vessels can occur at temperatures below about $650^{\circ} \mathrm{C}$ $\left(1200^{\circ} \mathrm{F}\right)$ when these materials (usually castable refractories) contain iron or iron alloys. An excellent review of this phenomenon, known as CO disintegration, can be found in ref. 9. Carbon deposition from the gas mixture is a necessary step in the process, which then leads to degradation that exhibits many of the same characteristics as metal dusting. Indeed, the basic mechanisms involved in both $\mathrm{CO}$ disintegration of iron-containing refractories and metal dusting appear to be the same, although, historically, the studies of the respective phenomena appear to have been conducted independently of each other.

Section 2 of this report summarizes the results of thermochemical calculations of carbon activities and stabilities of iron-containing phases for representative gasifier systems. These calculations show that, in all cases, a driving force for carbon formation on solid surfaces exists at the operating temperatures of the gasifier components, but that the requisite carbide phase necessary for metal dusting is not always thermodynamically favored. Section 3 briefly reviews possible materials and system factors that can influence the kinetics of carbon deposition. Section 4 is a summary of work related to metal dusting. It includes a description of the mechanisms for the processes leading to metal dusting based on what appears to be the most compelling experimental results and theoretical considerations. The relative susceptibilities of different alloys to metal dusting are also reported. The influence of system operating parameters on carbon deposition, carbide stability, and metal dusting is discussed in Sect. 5, and materials selection considerations for hot-gas cleanup sections of coal gasification systems are presented in Sect. 6. A systems analysis to determine what, if any, deleterious effects might occur as a result of possible process variations is beyond the scope of the present review. Thus, these considerations are not to be interpreted as recommendations unless such an analysis confirms their acceptability. It is concluded that experimental verification of the predictions based on thermodynamic information and assumptions regarding kinetics will be required, and approaches to this and other issues are described in Sect. 7. Private communications to the authors regarding the occurrence of metal dusting in operating gasifiers are summarized in Appendix A. 


\section{THERMOCHEMICAL CALCULATIONS FOR REPRESENTATIVE GASIFIER SYSTEMS}

As stated in Sect. 1, the initiation of carbon deposition and metal dusting requires a carbon activity greater than unity. For this reason, the product gas chemistries of eight representative gasifier systems were examined with respect to the chemical activity of carbon. A principal concern is the change in carbon activity brought about by reduction in the gas temperature downstream from the outlet of the gasifier reaction vessel; such cooling may accompany filtration and sulfur removal functions. The selected systems and their nominal gas compositions are listed in Tables 1 and 2, which present input data for air-blown and oxygen-blown systems, respectively.

The principal components of the product gas include $\mathrm{CO}, \mathrm{CO}_{2}, \mathrm{H}_{2}, \mathrm{H}_{2} \mathrm{O}, \mathrm{CH}_{4}$, and, in the case of air-blown gasifiers, $\mathrm{N}_{2}$. Minor species include $\mathrm{H}_{2} \mathrm{~S}, \mathrm{NH}_{3}$, and $\mathrm{COS}$. A series of thermochemical calculations, based on the SOLGASMIX ${ }^{10}$ computer program, was made to examine essentially all of the possible chemical interactions among these species as a function of temperature at representative system pressures. The calculations assumed that the mole fractions of the elemental constituents $(\mathrm{C}, \mathrm{H}, \mathrm{O}, \mathrm{S}$, and $\mathrm{N})$ in the compounds composing the reference product gas do not change from point to point in the system, and therefore do not vary with the gas temperature. This assumption appears valid given the conditions of forced convective

Table 1. Gas composition and pressures of reference air-blown gasifiers

\begin{tabular}{lccccc}
\hline \multirow{2}{*}{$\begin{array}{c}\text { Gas } \\
\text { component }\end{array}$} & $\begin{array}{c}\text { M. W. } \\
\text { Kellogg/ } \\
\text { Piñon Pine }\end{array}$ & $\begin{array}{c}\text { Foster } \\
\text { Wheeler/ } \\
\text { Wilsonville }\end{array}$ & $\begin{array}{c}\text { M. W. } \\
\text { Kellogg/ } \\
\text { Wilsonville }\end{array}$ & $\begin{array}{c}\text { Foster } \\
\text { Wheeler/ } \\
\text { Four Rivers }\end{array}$ & $\begin{array}{c}\text { Tampella } \\
\text { U-Gas/ } \\
\text { Toms Creek }\end{array}$ \\
\hline $\mathrm{CO}$ & 23.89 & 18.05 & 18.43 & 16.50 & 26.0 \\
$\mathrm{CO}_{2}$ & 5.44 & 8.79 & 8.10 & 9.00 & 5.0 \\
$\mathrm{H}_{2} \mathrm{O}$ & 5.50 & 9.11 & 8.07 & 9.50 & 14.0 \\
$\mathrm{H}_{2}$ & 14.57 & 16.57 & 13.70 & 12.90 & 5.0 \\
$\mathrm{CH}_{4}$ & 1.35 & 3.97 & 0.36 & 1.40 & 2.2 \\
$\mathrm{~N}_{2}$ & 48.65 & 42.68 & 51.30 & 50.50 & 47.5 \\
$\mathrm{H}_{2} \mathrm{~S}$ & 0.03 & 0.05 & 0.02 & 0.04 & 0.006 \\
$\mathrm{NH}_{3}$ & 0.02 & 0.32 & 0.01 & 0.19 & 0.15 \\
Ar/other & 0.56 & 0.48 & 0.02 & & \\
\hline Gas pressure & 20.26 & 14.19 & 20.68 & 14.18 & 22.65 \\
(bar) & & & & & \\
\hline
\end{tabular}


Table 2. Gas compositions and pressures of reference oxygen-blown gasifiers

\begin{tabular}{lccc}
\hline \multirow{2}{*}{ Gas component } & \multicolumn{3}{c}{ Concentration (vol \%) } \\
\cline { 2 - 4 } & Shell & British Gas/ & Lurgi \\
\hline $\mathrm{CO}$ & 62.9 & 54.1 & 46.5 \\
$\mathrm{CO}_{2}$ & 1.3 & 3.2 & 15.3 \\
$\mathrm{H}_{2} \mathrm{O}$ & 0.2 & 0.0 & 0.0 \\
$\mathrm{H}_{2}$ & 30.8 & 27.7 & 35.9 \\
$\mathrm{CH}_{4}$ & 0.035 & 7.0 & 0.0 \\
$\mathrm{~N}_{2}$ & 4.4 & 6.8 & 2.0 \\
$\mathrm{H}_{2} \mathrm{~S}$ & 0.4 & 0.0 & 0.3 \\
Ar/other & & & 0.1 \\
\hline Gas pressure (bar) & 28.58 & 22.05 & 35.13 \\
\hline
\end{tabular}

flow in a closed piping system and limited reaction of the gas with its containment system. Based on these calculations, the following generalizations can be applied to all gasifier systems and their attendant product gas compositions:

1. The equilibrium gas composition and, accordingly, the carbon activity are determined by three principal chemical reactions:

$$
\begin{gathered}
2 \mathrm{CO}(\mathrm{g})=\mathrm{CO}_{2}(\mathrm{~g})+\mathrm{C}(\mathrm{s}) \\
\mathrm{CO}_{2}(\mathrm{~g})+\mathrm{H}_{2}(\mathrm{~g})=\mathrm{H}_{2} \mathrm{O}(\mathrm{g})+\mathrm{CO}(\mathrm{g}) \\
\mathrm{CH}_{4}(\mathrm{~g})=\mathrm{C}(\mathrm{s})+2 \mathrm{H}_{2}(\mathrm{~g})
\end{gathered}
$$

Thus changes in the carbon activity of the product gas as a function of temperature (at a given system pressure) are controlled by the temperature dependencies of the standard free energies of these three reactions.

2. For a given gas composition, the effect of increasing the system operating pressure is to increase the effective carbon activity of the gas by reaction 1 and to decrease it by reaction 3 .

3. Nitrogen is an intrinsic gas species in air-blown gasifiers. By diluting the product gas, $\mathbf{N}_{\mathbf{2}}$ can indirectly affect the carbon activity. For example, proportional reductions in the $\mathrm{CO}$ and $\mathrm{CO}_{2}$ partial pressures brought about by the presence of $\mathrm{N}_{2}$ will decrease the carbon activity through reaction 1 , while the decreases in the $\mathrm{CH}_{4}$ and $\mathrm{H}_{2}$ partial pressures will increase the carbon activity through reaction 3 . However, even in air-blown gasifiers, $\mathbf{N}_{2}$ of itself is not sufficiently reactive to interact significantly with carbon or hydrogen; that is, gaseous products such as $\mathrm{NH}_{3}$ are relatively unstable. 
4. Even at the $\mathrm{H}_{2} \mathrm{~S}$ concentrations associated with the highest sulfur coals, the sulfur availability is too small to affect the concentration of the principal carbon- or hydrogen-containing species. Therefore, the carbon activity is unaffected by the presence of $\mathrm{H}_{2} \mathrm{~S}$.

For air-blown gasifiers, the calculations indicated that the gas compositions exiting the gasifier reactor (Table 1) are at equilibrium with respect to the exit gas temperature. The carbon activity at this point is less than unity. Typically, as the gas is cooled under equilibrium conditions, the $\mathrm{CO}$ and $\mathrm{H}_{2}$ concentrations decrease while the $\mathrm{CO}_{2}, \mathrm{H}_{2} \mathrm{O}$, and $\mathrm{CH}_{4}$ concentrations increase, and these changes are accompanied by a significant increase in the carbon activity. The temperature at which the carbon activity reaches unity is process-and fuel-dependent, but for the air-blown gasifiers examined, it ranged from a low of $770^{\circ} \mathrm{C}\left(1420^{\circ} \mathrm{F}\right)$ to a high of $880^{\circ} \mathrm{C}\left(1620^{\circ} \mathrm{F}\right)$.

In the case of oxygen-blown gasifiers, where the initial CO content was 54 vol \% or greater, calculations showed that the carbon activity of the gas was already higher than unity at the reference reactor outlet temperature. Again, cooling under equilibrium conditions resulted in a decrease in the $\mathrm{CO}$ and $\mathrm{H}_{2}$ concentrations and an increase in $\mathrm{CH}_{4}, \mathrm{CO}_{2}$, and $\mathrm{H}_{2} \mathrm{O}$ levels, while the carbon activity remained at unit activity. For the Texaco gasifier, in which the initial CO content was only $46.5 \mathrm{vol} \%$, the carbon activity was more typical of an air-blown system, and unit carbon activity was not established until the temperature had dropped to $870^{\circ} \mathrm{C}\left(1600^{\circ} \mathrm{F}\right)$.

The formation of $\mathrm{CH}_{4}$ is promoted by decreasing temperature, and, in effect, $\mathrm{CH}_{4}$ becomes a sink for carbon as the temperature is lowered. Accordingly, reaction 3 acts to offset the increase in carbon activity with decreasing temperature resulting from reaction 1 . However, without the action of an effective catalyst, reaction 3 is relatively sluggish and tends to be ineffective at temperatures below $800^{\circ} \mathrm{C}\left(1470^{\circ} \mathrm{F}\right)$. Accordingly, calculations of the $\mathrm{CH}_{4}$ gas concentration assuming equilibrium conditions for reaction 3 can be expected to give unrealistically high $\mathrm{CH}_{4}$ concentrations at lower temperatures. To examine this effect, another series of calculations was made in which reaction 3 was excluded, and the $\mathrm{CH}_{4}$ concentration was assumed to remain unchanged as the product gas was cooled. An unexpected finding in these latter calculations was that excluding reaction 3 had only a small effect on the temperature at which unit carbon activity was reached, and this temperature in some cases even decreased slightly. (This result appears to be associated with the relatively high $\mathrm{H}_{2}$ level in the product gases compared with the level of $\mathrm{CH}_{4}$ and the combined role of $\mathrm{H}_{2}$ in reactions 2 and 3.) However, once the temperature dropped below the unit carbon activity threshold, the elimination of reaction 3 significantly increased the carbon activity (or availability of solid carbon) upon further cooling.

The significant findings of these calculations relative to carbon deposition are summarized in graphical form in Figs. 1 through 4 . The results could be presented either in terms of the effective carbon activity of the gas excluding carbon in solid form or, as selected here, in terms of the availability of solid carbon in the gas, assuming no carbon had deposited at temperatures higher than the reference temperature. Figures 1 and 2 compare the carbon availability (moles of carbon/100 moles of gas) for selected air-blown gasifier systems (Table 1) with and without $\mathrm{CH}_{4}$ formation, respectively, and Figs. 3 and 4 compare the same calculations for oxygen-blown gasifiers (Table 2). The temperatures at which the respective plots intersect the abscissa represent those at which unit carbon activity is initially achieved. In the case of oxygen-blown systems with initial CO concentrations of $60 \%$ or greater, the carbon availability is several times higher than that of all other systems. The Texaco (oxygen-blown) gasifier, with an initial CO concentration of $46.5 \%$, has a relatively low carbon availability compared with air-blown systems when equilibrium $\mathrm{CH}_{4}$ levels are assumed, but the carbon availability is significantly higher if $\mathrm{CH}_{4}$ formation is excluded. The central conclusion to be drawn from these plots is that, from a thermodynamic standpoint, the potential for carbon deposition will exist for all gasifier systems at some temperature below that attained in the reaction vessel. This potential arises from the relatively high $\mathrm{CO}$ concentration in the product gas. Based on equilibrium calculations, $\mathrm{H}_{2}$ will act to offset the extent of carbon deposited through the generation of $\mathrm{CH}_{4}$, but this reaction is very sluggish at the temperatures at which carbon deposition will occur. The temperature at which deposition becomes possible is directly proportional to the $\mathrm{CO}$ content of the gas and may increase or decrease slightly with higher $\mathrm{H}_{2}$ contents. 


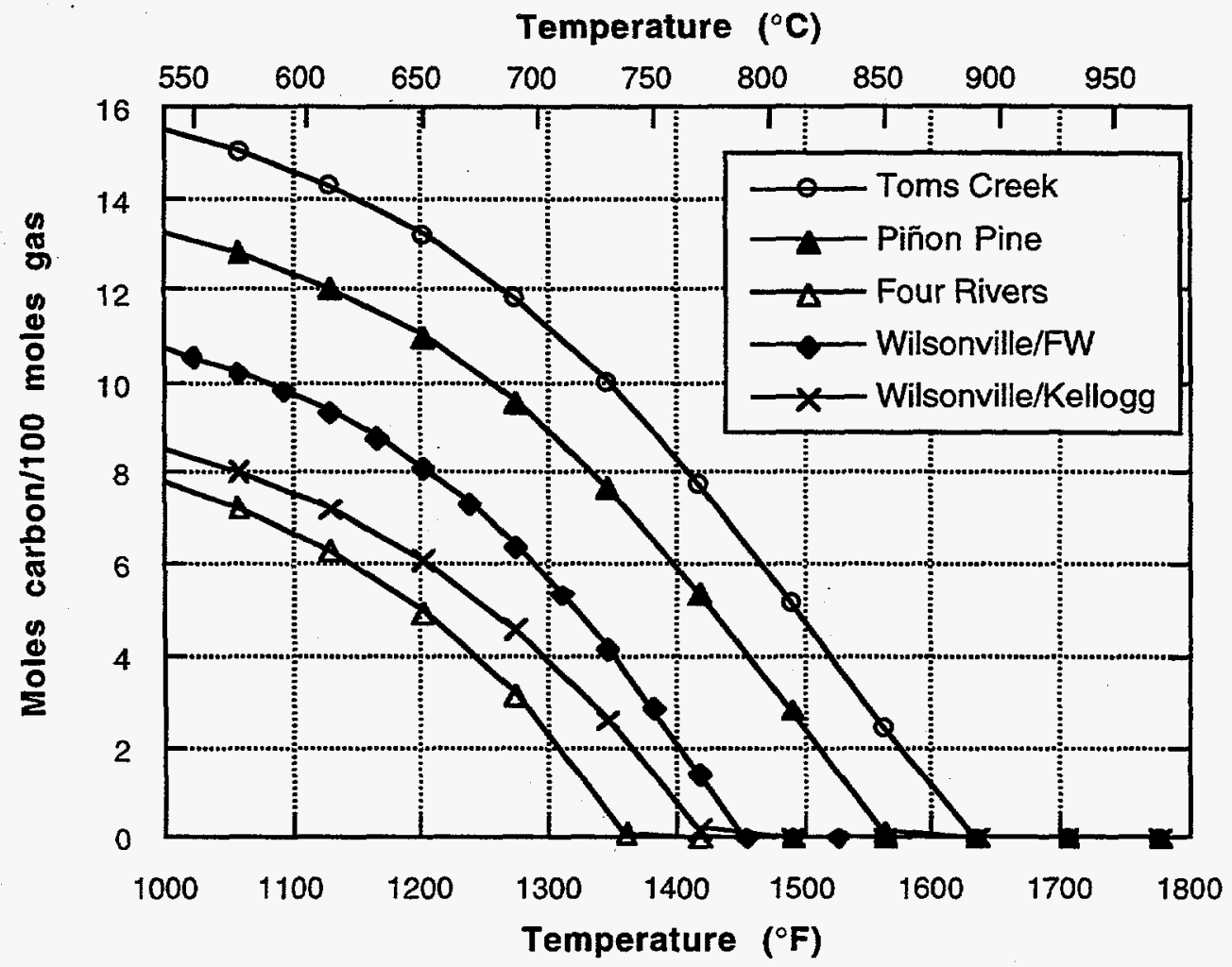

Fig. 1. SOLGASMIX-calculated equilibrium levels of solid carbon showing temperature at which unit $a_{c}$ is achieved for various air-blown gasifiers.

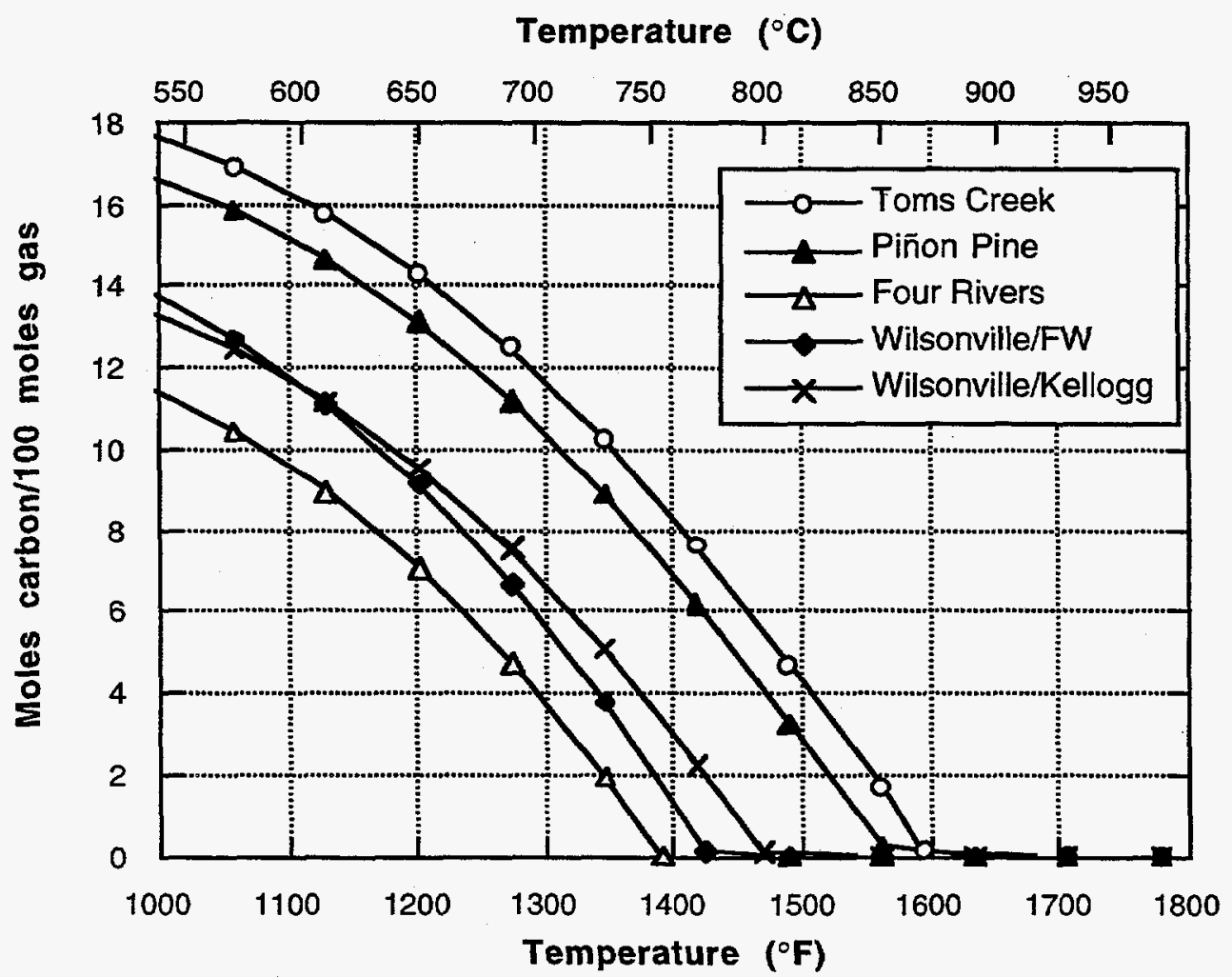

Fig. 2. SOLGASMIX-calculated equilibrium levels of solid carbon showing temperature at which unit $a_{c}$ is achieved for various air-blown gasifiers under the assumption of no methane formation. 


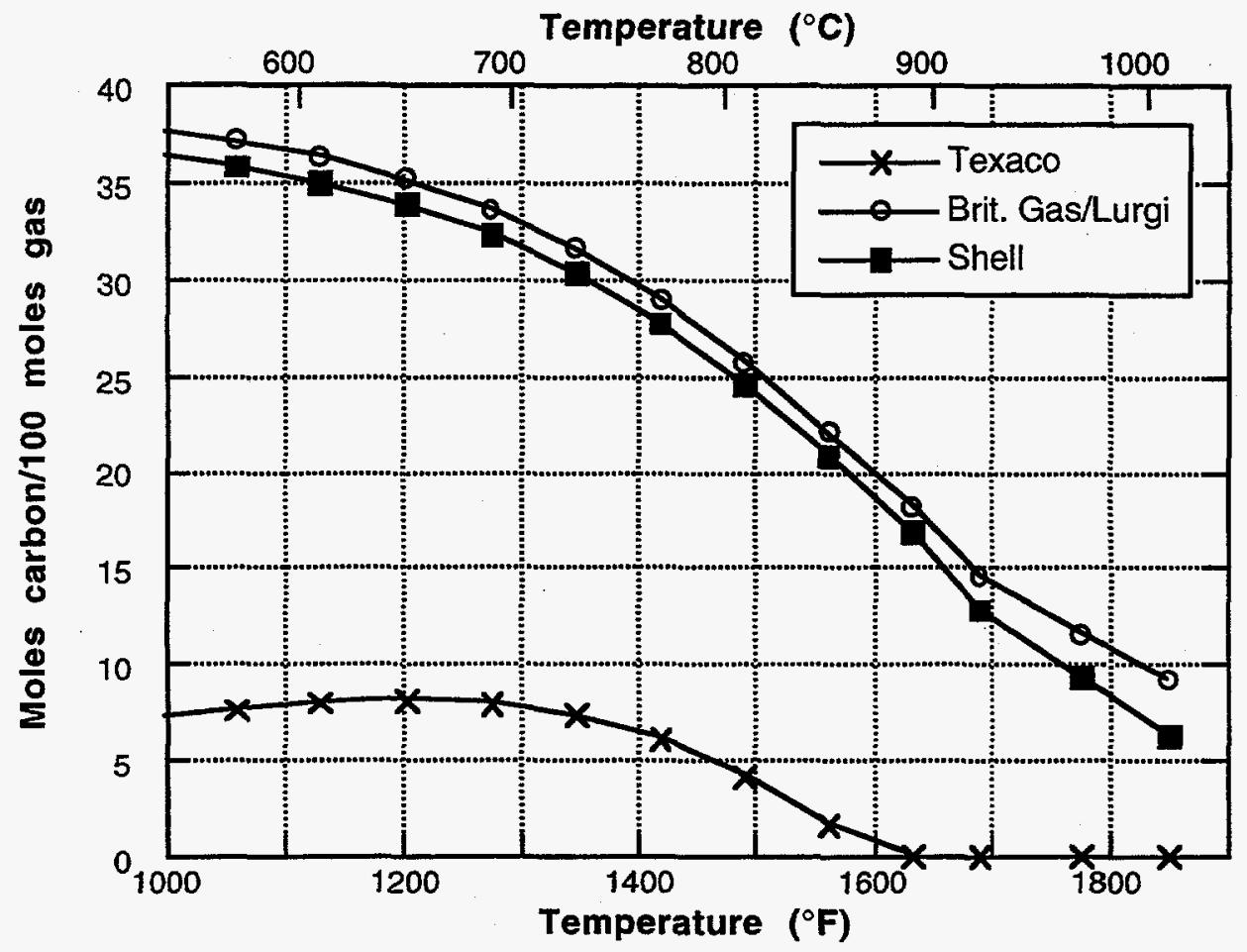

Fig. 3. SOLGASMIX-calculated equilibrium levels of solid carbon showing temperature at which unit $a_{c}$ is achieved for various oxygen-blown gasifiers.

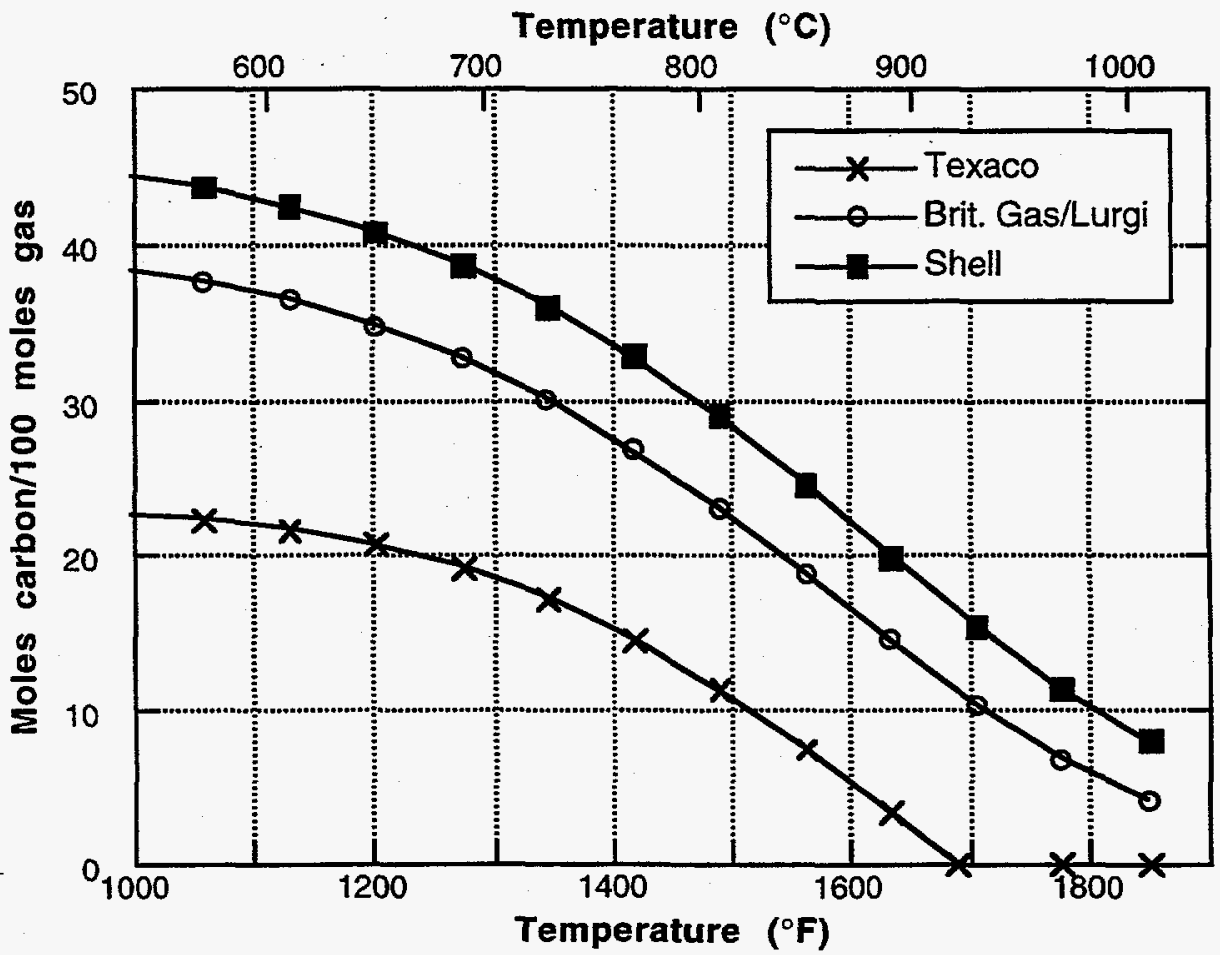

Fig. 4. SOLGASMIX-calculated equilibrium levels of solid carbon showing temperature at which unit $a_{c}$ is achieved for various oxygen-blown gasifiers under the assumption of no methane formation. 
Because the formation of a metastable carbide $\left(\mathrm{Fe}_{3} \mathrm{C}\right.$, for steels) is a necessary condition for metal dusting, determination of solid-phase stabilities in different gasifier environments is an important aspect of evaluating the potential for degradation of exposed materials. Accordingly, equilibrium calculations were performed to determine the phase stability of iron-containing reaction products in contact with the product gases of air-and oxygen-blown gasifiers at 600 and $800^{\circ} \mathrm{C}\left(1110\right.$ and $\left.1470^{\circ} \mathrm{F}\right)$, respectively. The Piñon Pine and Foster Wheeler/Wilsonville reference gas compositions in Table 1 were arbitrarily selected from the air-blown category, while the Shell gasifier composition in Table 2 was selected from the oxygen-blown class. The phase-stability relationships were initially determined under equilibrium considerations that limited the carbon activity to that of the most stable carbon-containing phase. Since the carbon activity of graphite $\left(a_{c}=1\right)$ is below that of the most stable carbide, $\mathrm{Fe}_{3} \mathrm{C}$, the formation of graphite supersedes that of $\mathrm{Fe}_{3} \mathrm{C}$ under equilibrium conditions. However, if the deposition of solid carbon from the product gas is relatively sluggish, such that the carbon activity of the gas can build up above that of graphite, then $\mathrm{Fe}_{3} \mathrm{C}$ formation becomes thermodynamically possible, particularly at lower temperatures. Accordingly, a second series of phase stability calculations was carried out in which solid carbon formation was suppressed. The $\mathrm{H}_{2} \mathrm{~S}$ concentrations used in the calculations were those listed for the given gasifiers in Tables 1 and 2. Note that the $\mathrm{H}_{2} \mathrm{~S}$ concentration can vary depending on the coal source and hot-gas cleanup system and that such changes will significantly affect the relative stability of iron sulfide in the system.

When graphite was allowed to form, phase stability calculations for both air-blown gasifiers indicated that iron oxide ( $\mathrm{FeO})$ predominated as the most stable iron-containing phase at $800^{\circ} \mathrm{C}\left(1470^{\circ} \mathrm{F}\right)$, and both iron sulfide $\left(\mathrm{Fe}_{0.877} \mathrm{~S}\right)$ and iron oxide were stable phases at $600^{\circ} \mathrm{C}\left(1110^{\circ} \mathrm{F}\right)$. Under these same conditions, only the $\mathrm{Fe}_{0.877} \mathrm{~S}$ phase was stable in the case of the oxygen-blown Shell gasifier. When the formation of solid carbon was suppressed but $\mathrm{CH}_{4}$ formation (reaction 3) was allowed, the results for the air-blown gasifiers were unchanged: $\mathrm{FeO}$ and $\mathrm{Fe}_{0.877} \mathrm{~S}$ were the principal phases at $600^{\circ} \mathrm{C}\left(1110^{\circ} \mathrm{F}\right)$, and $\mathrm{FeO}$ alone was predominant at $800^{\circ} \mathrm{C}\left(1470^{\circ} \mathrm{F}\right)$. However, if the reaction to form $\mathrm{CH}_{4}$ was suppressed along with the one to form solid carbon, then $\mathrm{Fe}_{3} \mathrm{C}$ and $\mathrm{Fe}_{0.877} \mathrm{~S}$ became the predominant phases at $600^{\circ} \mathrm{C}\left(1110^{\circ} \mathrm{F}\right)$ for both air-blown gasifiers. At $800^{\circ} \mathrm{C}\left(1470^{\circ} \mathrm{F}\right), \mathrm{Fe}_{3} \mathrm{C}$ was the predominant phase in the case of the Piñon Pine gasifier, while $\mathrm{Fe}_{0.877} \mathrm{~S}$ and $\mathrm{FeO}$ were predominant in the case of the Foster Wheeler/Wilsonville gasifier. When the formation of graphite was suppressed in the case of the oxygen-blown Shell gasifier, the $\mathrm{Fe}_{0.877} \mathrm{~S}$ phase remained stable and the $\mathrm{Fe}_{3} \mathrm{C}$ phase did not appear even when the $\mathrm{CH}_{4}$ reaction was suppressed. Only by lowering the $\mathrm{H}_{2} \mathrm{~S}$ content of the gas to below 0.20 vol $\%$ at $600^{\circ} \mathrm{C}\left(1110^{\circ} \mathrm{F}\right)$ and 0.32 vol $\%$ at $800^{\circ} \mathrm{C}\left(1470^{\circ} \mathrm{F}\right)$ could stability be conferred to the $\mathrm{Fe}_{3} \mathrm{C}$ phase, where it coexisted with $\mathrm{Fe}_{0.87} \mathrm{~S}$. At $\mathrm{H}_{2} \mathrm{~S}$ concentrations below 0.09 vol $\%$ at $600^{\circ} \mathrm{C}\left(1110^{\circ} \mathrm{F}\right)$ and $0.20 \mathrm{vol} \%$ at $800^{\circ} \mathrm{C}\left(1470^{\circ} \mathrm{F}\right), \mathrm{Fe}_{3} \mathrm{C}$ became the predominant phase. Similar calculations indicated that nitrogen-containing reaction products with iron would not be expected to form under equilibrium conditions even for air-blown gasifiers. A summary of the phase-stability relationships for these three gasifiers is shown in Table 3.

For the air-blown gasifiers, the appearance of the $\mathrm{Fe}_{3} \mathrm{C}$ phase coincided with the disappearance of the iron oxide phase, which was a result of the oxygen activity of the system being reduced by the relatively high carbon activity. These phase stability calculations indicate that the formation of $\mathrm{Fe}_{3} \mathrm{C}$ is precluded thermodynamically under conditions where an oxide can form, a finding that suggests that an $\mathrm{FeO}$ scale should be effective in mitigating metal dusting. The sulfide reaction product in the air-blown gasifiers was found to coexist with either the oxide or the carbide. However, in the oxygen-blown Shell gasifier, the oxide was not thermodynamically stable, and, because of the relatively high $\mathrm{H}_{2} \mathrm{~S}$ concentration (1.4 vol \%), the sulfide existed to the exclusion of the carbide. It follows that at higher $\mathrm{H}_{2} \mathrm{~S}$ concentrations the sulfide can act effectively to exclude formation of $\mathrm{Fe}_{3} \mathrm{C}$ in the same manner as an oxide, while at lower $\mathrm{H}_{2} \mathrm{~S}$ levels, where it coexists with the carbide, its effectiveness as a barrier to $\mathrm{Fe}_{3} \mathrm{C}$ will depend on the relative nucleation and growth rates of the carbide vis-a-vis the sulfide. Because the reaction rate to form iron sulfide is significantly faster than that of iron oxide at $600^{\circ} \mathrm{C}\left(1110^{\circ} \mathrm{F}\right),{ }^{11}$ the stability of iron sulfide in this temperature range, as shown by these calculations, could be a significant factor in inhibiting the formation of $\mathrm{Fe}_{3} \mathrm{C}$. A general conclusion from these stability calculations is that removal of $\mathrm{H}_{2} \mathrm{~S}$ by a hot-gas cleanup system may have less effect on the formation 
Table 3. Predominant solid-state phases of iron when exposed to reference product gas components

\begin{tabular}{|c|c|c|c|c|}
\hline \multirow[b]{2}{*}{ Gasifier system } & \multirow[b]{2}{*}{$\begin{array}{c}\text { Temperature } \\
\left({ }^{\circ} \mathrm{C}\right) \\
\end{array}$} & \multicolumn{3}{|c|}{ Predominant phases } \\
\hline & & $\begin{array}{c}\text { Fully } \\
\text { equilibrated }\end{array}$ & $\begin{array}{c}\text { Carbon } \\
\text { deposition } \\
\text { suppressed } \\
\end{array}$ & $\begin{array}{c}\text { Carbon } \\
\text { deposition and } \\
\mathrm{CH}_{4} \text { formation } \\
\text { suppressed } \\
\end{array}$ \\
\hline \multirow[t]{2}{*}{$\begin{array}{l}\text { Piñon Pine } \\
\text { (M. W. Kellogg) }\end{array}$} & 600 & $\begin{array}{l}\text { Graphite, FeO, } \\
\text { FeS }\end{array}$ & $\mathrm{FeO}, \mathrm{FeS}$ & $\mathrm{FeS}, \mathrm{Fe}_{3} \mathrm{C}$ \\
\hline & 800 & Graphite, FeO & $\mathrm{FeO}$ & $\mathrm{Fe}_{3} \mathrm{C}$ \\
\hline \multirow[t]{2}{*}{$\begin{array}{l}\text { Foster Wheeler/ } \\
\text { Wilsonville }\end{array}$} & 600 & $\begin{array}{l}\text { Graphite, FeO, } \\
\text { FeS }\end{array}$ & $\mathrm{FeO}, \mathrm{FeS}$ & $\mathrm{FeS}, \mathrm{Fe}_{3} \mathrm{C}$ \\
\hline & 800 & $\mathrm{FeO}$ & $\mathrm{FeO}$ & $\mathrm{FeO}, \mathrm{FeS}$ \\
\hline \multirow{2}{*}{$\begin{array}{l}\text { Shell } \\
\text { (oxygen-blown) }\end{array}$} & 600 & Graphite, FeS & $\mathrm{FeS}$ & $\mathrm{FeS}^{a}$ \\
\hline & 800 & Graphite, FeS & FeS & $\mathrm{FeS}^{b}$ \\
\hline
\end{tabular}

${ }^{a} \mathrm{Fe}_{3} \mathrm{C}$ is also stable if $\mathrm{H}_{2} \mathrm{~S}<0.2 \mathrm{vol} \%$.

${ }^{b} \mathrm{Fe}_{3} \mathrm{C}$ is also stable if $\mathrm{H}_{2} \mathrm{~S}<0.32$ vol \%.

of $\mathrm{Fe}_{3} \mathrm{C}$ (and therefore on metal dusting) in the two air-blown gasifier environments, where the iron oxide phase can exist and is unaffected by the removal of sulfur, than in the Shell product gas environment, where iron sulfide provides the only significant potential barrier to $\mathrm{Fe}_{3} \mathrm{C}$ formation.

Kinetic effects can be expected to play an important role relative to carbon deposition in gasifier systems, considering that deposition is possible only at reduced gas temperatures. (These effects, particularly those associated with $\mathrm{H}_{2} \mathrm{~S}$ and $\mathrm{NH}_{3}$, are discussed in Sect. 3.) In fact, on the basis of the reactions 1, 2, and 3, it appears more fruitful to approach the problem of controlling carbon deposition in gasifiers by inhibiting the kinetics of the reactions rather than by altering the concentrations of major gas species. An example is the effect of adding steam to one of the reference air-blown product gases, namely, the Piñon Pine reference composition (Table 1). Equilibrium calculations were made in which the concentration of steam was doubled from the initial level of $5.5 \mathrm{vol} \%$ to a level of $11 \mathrm{vol} \%$ without changing the relative concentrations of the other gases. Even such a large steam injection did not eliminate the potential for carbon deposition, although it did lower the temperature at which unit carbon activity is achieved from $850^{\circ} \mathrm{C}\left(1560^{\circ} \mathrm{F}\right)$, the temperature shown in Fig. 1, to $798^{\circ} \mathrm{C}\left(1468^{\circ} \mathrm{F}\right)$. Accordingly, the injection of steam does not eliminate the possibility of carbon deposition, although by lowering the threshold temperature for solid carbon formation it could possibly inhibit the reaction based on kinetic effects.

Another aspect of increasing the steam content of the product gas is the effect on corrosion products formed by reaction with the containment material. By increasing the oxygen potential of the gas, steam injection could promote the formation of oxide reaction products, which may serve to prevent development of $\mathrm{Fe}_{3} \mathrm{C}$. Accordingly, the effect of doubling the steam content of the Piñon Pine gasifier to $11 \%$ was also examined from the standpoint of its effect on the phase stability of iron-containing reaction products. As already shown, if the formation of solid carbon is suppressed, the predominant phases formed in the nominal Pinon Pine product gas, containing 5.5\% $\mathrm{H}_{2} \mathrm{O}$, are $\mathrm{FeO}$ and $\mathrm{Fe}_{0.87} \mathrm{~S}$ at $600^{\circ} \mathrm{C}\left(1110^{\circ} \mathrm{F}\right)$ and $\mathrm{FeO}$ at $800^{\circ} \mathrm{C}$ $\left(1470^{\circ} \mathrm{F}\right)$. Increasing the $\mathrm{H}_{2} \mathrm{O}$ content to $11 \%$ in this case did not change the stable ensembles at either 
temperature. In the case where the formation of both solid carbon and $\mathrm{CH}_{4}$ (reaction 3 ) is suppressed, increasing the $\mathrm{H}_{2} \mathrm{O}$ content to $11 \%$ has no effect at $600^{\circ} \mathrm{C}\left(1110^{\circ} \mathrm{F}\right)$ but is beneficial at $800^{\circ} \mathrm{C}\left(1470^{\circ} \mathrm{F}\right)$. Both $\mathrm{Fe}_{0.877} \mathrm{~S}$ and $\mathrm{Fe}_{3} \mathrm{C}$ are retained as the predominant phases at $600^{\circ} \mathrm{C}$, while at $800^{\circ} \mathrm{C}$, the $\mathrm{Fe}_{3} \mathrm{C}$ phase, predominant in the nominal atmosphere, is, in fact, supplanted by FeO. It appears that $\mathrm{H}_{2} \mathrm{O}$ additions could provide an overriding effect on iron carbide formation at higher temperatures, where the carbon activity of the gas is more moderate, but very large additions would be required at lower temperatures to offset the larger carbon activities that can accrue if solid carbon deposition and $\mathrm{CH}_{4}$ production fail to keep pace with carbon-forming reactions (such as reaction 1). 


\section{CONDITIONS THAT INFLUENCE KINETICS OF CARBON DEPOSITION}

As shown in Sect. 2, essentially all representative gasifiers operate under conditions in which carbon formation is thermodynamically possible in the hot-gas cooler and cleanup sections. However, such calculations do not take account of the kinetics of the gas equilibration or carbon deposition processes, since all chemical reactions are assumed to proceed sufficiently rapidly so that thermodynamic equilibrium is achieved. Typically, methods exist to increase or decrease the rates of reaction either through gas-phase modifications or by altering the surfaces on which carbon deposition is to take place. Furthermore, under some operating conditions, carbon formation can be significantly reduced by quenching the gas to minimize its residence time at temperatures where deposition occurs.

There is much controversy concerning the identity of the active catalyst for the disproportionation of carbon monoxide in steel systems. ${ }^{8}$ The loss of catalytic activity of iron in the formation of carbon has been observed to be accompanied by conversion of the iron to $\mathrm{Fe}_{3} \mathrm{C} .{ }^{12}$ Hydrogen was effective in reactivating the catalyst, supposedly by converting the $\mathrm{Fe}_{3} \mathrm{C}$ back to iron. ${ }^{12}$ However, there are some compelling arguments that the formation of $\mathrm{Fe}_{3} \mathrm{C}$ is necessary before carbon will deposit. ${ }^{13}$

The poisoning effect of $\mathrm{H}_{2} \mathrm{~S}$ on carbon deposition reactions has long been known. ${ }^{14-16}$ This compound is routinely added to gas mixtures of high carbon activity to reduce degradation that involves carbon deposition as a precursor to carburization. ${ }^{217-21}$ It is generally assumed that the sulfide acts to reduce the catalytic activity of surfaces with respect to carbon deposition. ${ }^{20}$ The presence of water vapor has also been reported to inhibit deposition of carbon, ${ }^{21}$ but not necessarily catalytically. Rather, water vapor can react with the deposit to form gaseous products or shift the equilibria of reactions 1,2 , and 3 so as to reduce $\mathrm{CO}$ decomposition. ${ }^{21}$ However, as discussed in Sect. 2, relatively large concentrations of water vapor would be required to materially affect carbon deposition in the typical gasifier.

The formation of stable surface layers of certain types of oxides has been shown to be effective in decreasing carbon formation and/or reducing the susceptibility to metal dusting (perhaps by preventing deposition on reactive surfaces). These oxides include chromia, silica, and, possibly, alumina. ${ }^{1,22,23}$ This effect will be discussed in more detail when alloying effects on metal dusting are reviewed in Sect. 4. Some surface oxides, such as $\mathrm{Fe}_{2} \mathrm{O}_{3}$ and $\mathrm{Fe}_{3} \mathrm{O}_{4}$, and carbides can actually increase carbon formation. ${ }^{3,8,9,24}$ In addition to oxidation effects, alloying or material selection and surface condition can also affect deposition by controlling the types of carbides that form or the phase distribution of the alloy components. ${ }^{24}$ Surface roughness increases carbon deposition rates. ${ }^{3,25}$ As may be expected, the surface crystallography can have an important effect (see, for example, ref. 26). 



\section{METAL DUSTING}

As defined in the Introduction, metal dusting is a severe form of corrosion that occurs when susceptible materials are exposed to environments with very high carbon activities. It results in uniform metal loss and/or severe pitting. The rate of degradation is significantly influenced by alloy composition and condition, the particular gas environment, temperature, and pressure. According to Hochman, ${ }^{2}$ this type of degradation was first observed in 1876 in the form of deterioration of iron in refractory brick used in blast furnaces (see the discussion of $\mathrm{CO}$ disintegration of refractories in the Introduction). However, it has only been within the last 35 years that much attention has been paid to metal dusting and, even then, the number of investigators who have devoted a significant amount of effort to its study is small. Nevertheless, systematic studies of this phenomenon (see, for example, the reviews in references 2 and 21) have shown that the manifestation of the typical metal dusting process results from a series of steps that occur in the following order: ${ }^{3}$

1. rapid uptake of carbon into the metallic phase leading to supersaturation of carbon in the alloy,

2. formation of metastable carbides (for steels, $\mathrm{Fe}_{3} \mathrm{C}$ ),

3. decomposition of these carbides (which are stable only at $a_{c}>1$ ) when localized deposition of carbon occurs $\left(\mathrm{a}_{\mathrm{c}}=1\right)$, and

4. development of a loosely adherent mixture of filamentary carbon and metallic particles, which then act as catalysts for further carbon deposition.

These steps are shown schematically in Fig. 5. Carbide formation and decomposition continues until the supersaturated region is consumed, but, if the reaction products are removed by erosion or other means, the process could start again. ${ }^{2}$ At longer times and following significant metal consumption, pitting is usually observed. $2,3,17,22,27$

Metal dusting for any given material tends to occur in a relatively narrow range $\left(100-200^{\circ} \mathrm{C}, 180-360^{\circ} \mathrm{F}\right)$ of the temperature regime from 400 to $900^{\circ} \mathrm{C}\left(750\right.$ to $\left.1650^{\circ} \mathrm{F}\right)$. The particular temperature window of susceptibility depends on the material, the gas composition, thermodynamic considerations, and kinetics. ${ }^{2,322.28,29}$ A schematic representation of the temperature dependence of reactivity for iron, cobalt, and nickel is shown in Fig. 6. The severity of the reaction does not necessarily increase with temperature, ${ }^{2,22}$ as many factors influence the process either directly or indirectly. The kinetics of the process for low-alloy steels have been recently studied by Grabke et al., ${ }^{17}$ who showed that the rate of metal wastage by $\mathrm{Fe}_{3} \mathrm{C}$ decomposition is linearly proportional to time $(t)$ and, as this reaction provides the catalysts for the carbon deposition, the mass of carbon increases in proportion to $t 2$.

Metal dusting can be inhibited by forming and maintaining a barrier layer between the gas phase and the reactive solid. Such a barrier would, by definition, be unreactive in the carburizing environment and would prevent rapid transport of carbon. Oxides of chromium, silicon, and aluminum appear to have the appropriate properties to protect underlying surfaces from reaction with carbon. ${ }^{2,22,23}$ The presence of less stable oxides (such as $\mathrm{Fe}_{2} \mathrm{O}_{3}$ or $\mathrm{Fe}_{3} \mathrm{O}_{4}$ ) on the outer surface of these protective scales can promote carbon deposition. (This could be of concern with the use of weathered steel as a containment material.) However, under the nominal conditions of these gasifiers, the prevailing low oxygen activities preclude the formation of these higher iron oxides. As described in Sect. 2, FeO and, under certain conditions, $\mathrm{Fe}_{0.877} \mathrm{~S}$ are thermodynamically favored over $\mathrm{Fe}_{3} \mathrm{C}$ and, therefore, should prevent metal dusting. 

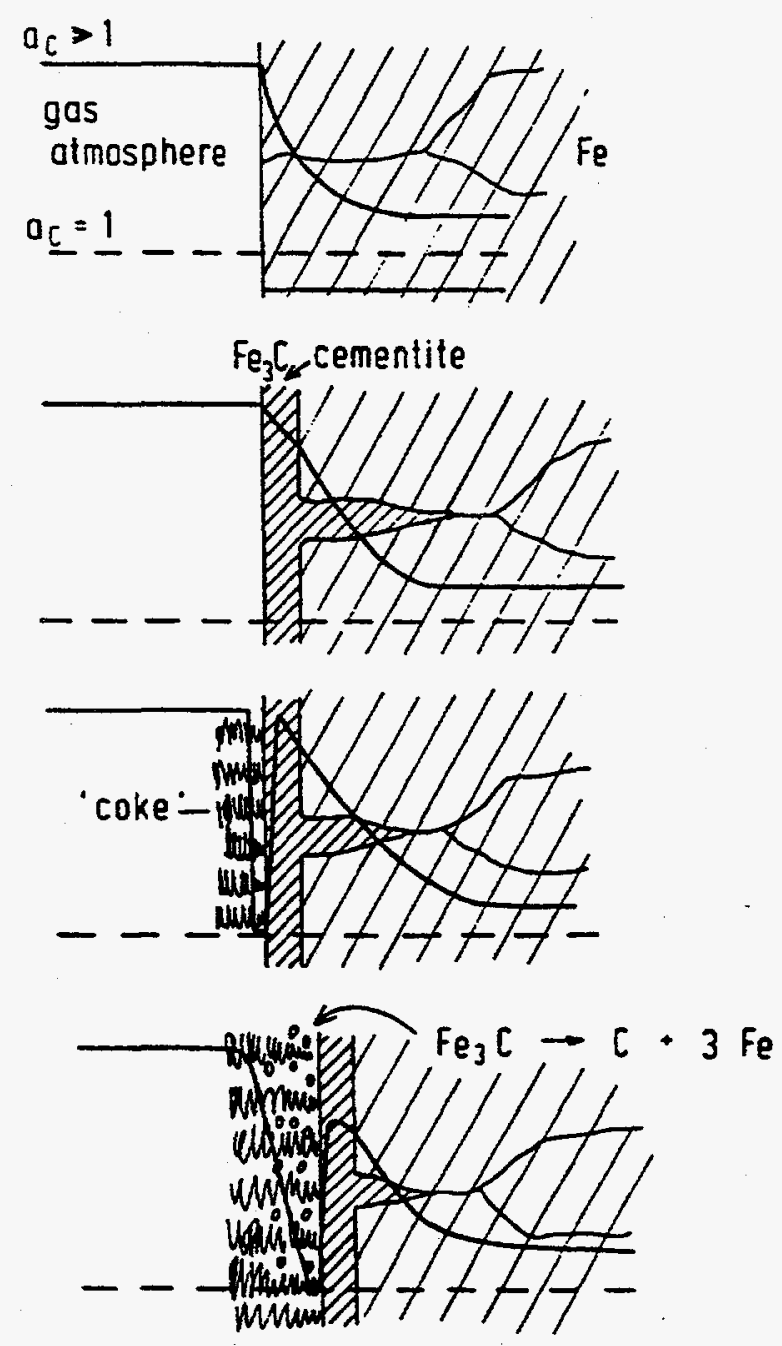

Fig. 5. Schematic representation of the steps involved in degradation by metal dusting. [From J. C. Nava Paz and H. J. Grabke, "Metal Dusting," Oxid. Met. 39, 437-56 (1993)]. 


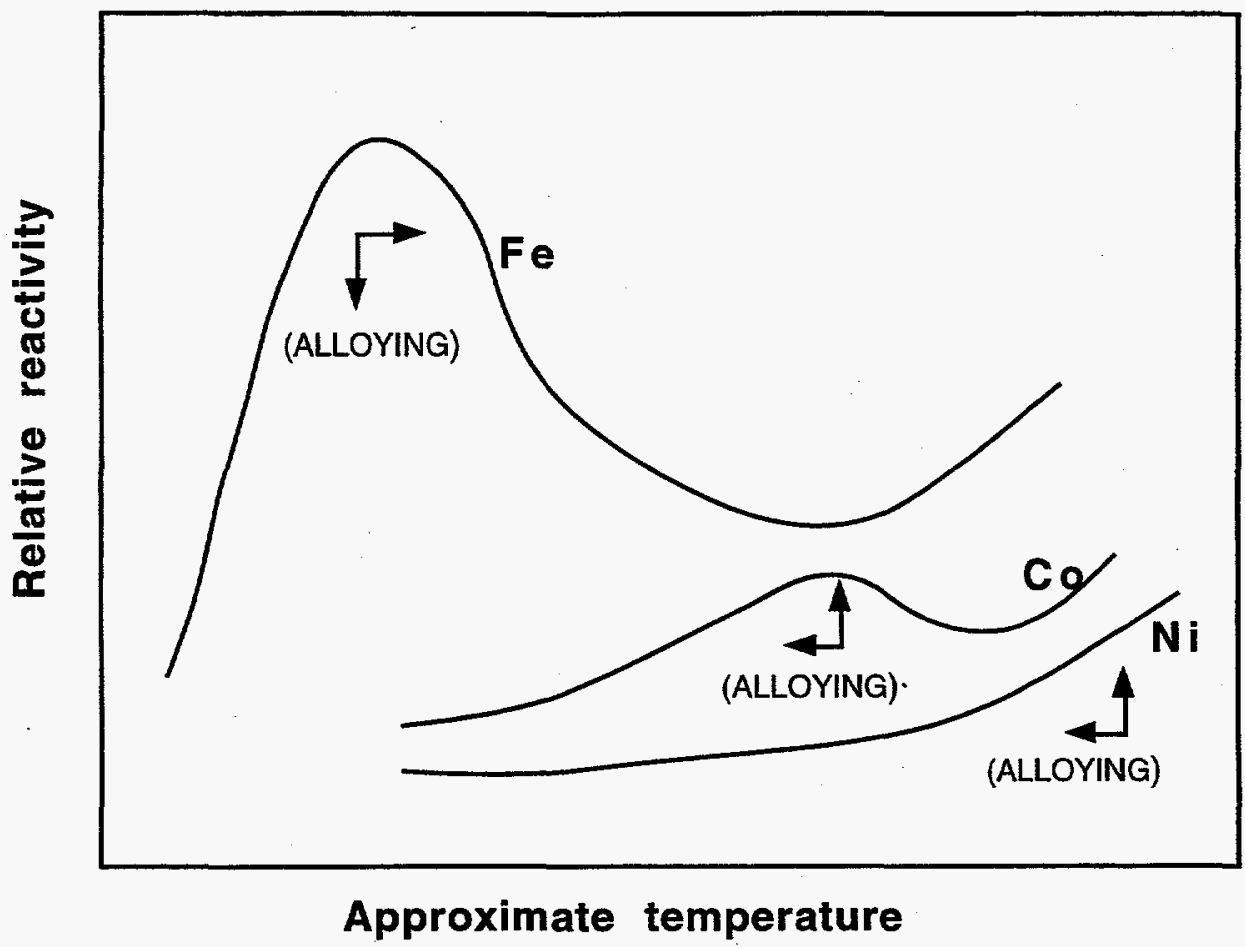

Fig. 6. Schematic representation of reactivity vs temperature for pure iron, nickel, and cobalt in $1 \mathrm{~atm}$ of pure $\mathbf{C O}$. The arrows indicate the shift in relative reactivity caused by most alloying additions. [From $R$. F. Hochman and J. H. Burson III, "The Fundamentals of Metal Dusting," API Division of Refining Proc. 46, $331-44(1966)]$.

Most of the metal-dusting experience with protective oxides relates to chromia, as chromium is the principal protective scale-forming alloying addition to stainless steels and heat-resistant alloys. ${ }^{2,22,27,28}$ For these materials, the resistance to metal dusting is principally governed by the ability of the alloy to develop a continuous chromia scale. When chromia formation is enhanced by compositional or microstructural modifications that increase chromium activity or diffusivity and/or by environmental manipulation, resistance to metal dusting can be significantly increased.,22 On the other hand, when the tendency to form chromia is purposely suppressed, metal dusting of the same alloys can occur. ${ }^{22,28}$

It is known that the presence of $\mathrm{H}_{2} \mathrm{~S}$ suppresses the attack of iron and low-alloy steels by metal dusting. ${ }^{217-19}$ The amount of $\mathrm{H}_{2} \mathrm{~S}$ in the gas phase need not be large; additions on the order of 20 to $200 \mathrm{ppm}$ can effectively eliminate metal dusting. ${ }^{2.17}$ This effect may be due to an inhibiting effect of $\mathrm{H}_{2} \mathrm{~S}$ on the carbon deposition rate. ${ }^{15,16,28}$ However, it could also relate to suppression of the formation of $\mathrm{Fe}_{3} \mathrm{C}$. As discussed in Sect. 2, the formation of iron sulfide can compete with the nucleation and growth of $\mathrm{Fe}_{3} \mathrm{C}$ and, at higher $\mathrm{H}_{2} \mathrm{~S}$ concentrations, $\mathrm{Fe}_{0.877} \mathrm{~S}$ can exist to the exclusion of the carbide. Alternatively, sulfur may be incorporated into $\mathrm{Fe}_{3} \mathrm{C}$ and will effectively stabilize it so that it does not decompose when $\mathrm{a}_{\mathrm{c}} \leq 1$ (see Fig. 5). ${ }^{2}$ Ammonia has also been reported to inhibit metal dusting, but not as effectively as sulfur. ${ }^{2}$ The beneficial effect of water vapor can probably be ascribed to the ability to oxidize an appropriate alloy to form an oxide layer. ${ }^{2}$ As shown in Sect. 2 , significant concentrations of water vapor can stabilize $\mathrm{FeO}$ rather than $\mathrm{Fe}_{3} \mathrm{C}$ on iron or low-alloy steels under gas conditions that normally would lead to formation of the carbide. 
Susceptibility of a particular alloy to metal dusting can usually be explained on the basis of the tendency for carbon deposition on its native surface, the formation of the appropriate metastable carbide, and the ability to form a protective surface oxide. Using iron or low-alloy steels as the reference point, addition of nickel decreases the rate of carbon deposition (see, for example, Fig. 7) and, therefore, the susceptibility to metal dusting. ${ }^{2,4}$ To a lesser extent, alloying with cobalt has a similar influence. ${ }^{2}$

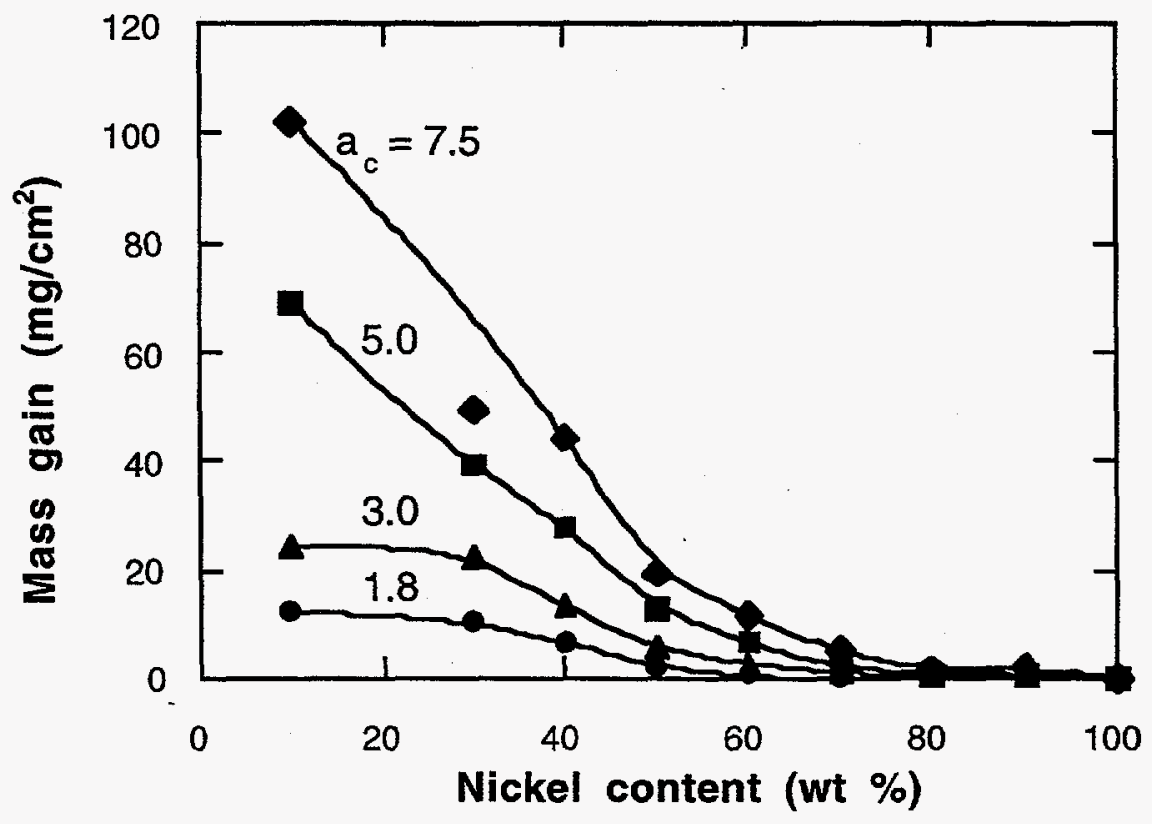

Fig. 7. Deposits on Fe-Ni alloys after $24 \mathrm{~h}$ of exposure in $\mathrm{CO}-\mathrm{H}_{2}-\mathrm{H}_{2} \mathrm{O}$ at $0.1 \mathrm{bar} \mathrm{CO}$ and $650^{\circ} \mathrm{C}$ as measured by mass gain as a function of nickel concentration. [From H. J. Grabke, R. Krajak, and J. C. Nava Paz, "On the Mechanism of Catastrophic Carburization: Metal Dusting," Corros. Sci. 35, 1141-50 (1993).]

As indicated in Fig. 6, alloying additions to iron generally decrease its susceptibility to metal dusting and increase its temperature of maximum reactivity, while additions to nickel or cobalt normally result in the opposite behavior. As already noted, alloys containing a large concentration of chromium show improved resistance to metal dusting because a continuous protective layer of chromia can form. Furthermore, in this regard, alloys in which chromium has a higher solid-state diffusivity are preferred, as the higher diffusivity aids the rapid development of the $\mathrm{Cr}_{2} \mathrm{O}_{3}{ }^{22}$ Based on these factors, high-alloy steels are better than low-alloy versions (because of their higher chromium contents), and ferritic stainless steels are better than austenitic ones (because of higher chromium diffusivity). If metal dusting occurs on higher-chromium alloys, degradation tends to be in the form of pits rather than general metal wastage. Silicon additions also show a beneficial effect on resistance to metal dusting by providing the means to form a protective layer of $\mathrm{SiO}_{2}{ }^{2.28}$ Hochman concluded that, as a rule, an alloy with $A$ wt $\% \mathrm{Cr}$ and $B$ wt \% Si would show reduced susceptibility to metal dusting if $A+2 \cdot B>24$ and if a stable surface oxide could be maintained. ${ }^{2}$ Comparative metal dusting results for a number of metals and alloys can be found in refs. 1,2, 20,22, and 30.

Very few results for alumina-forming alloys are available. However, if an alloy can form a sound, stable $\mathrm{Al}_{2} \mathrm{O}_{3}$ surface layer, it should be resistant to metal dusting in a manner similar to the way steels are protected by chromia films. Hochman reported some general, preliminary results showing such an effect. ${ }^{2}$ Furthermore, 
alumina scales are thermodynamically stable at even lower oxygen activities than chromia. ${ }^{11}$ Initial tests with an iron aluminide revealed susceptibility to metal dusting, probably through the formation of metastable $\mathrm{Fe}_{3} \mathrm{AlC} .{ }^{31}$ However, it may be possible to use preoxidation treatments (such as those discussed in Sect. 5) to establish an alumina layer on the iron aluminide and prevent such degradation.

For a given alloy, microstructural manipulation can also affect susceptibility to metal dusting. This can occur directly through effects on carbon deposition or carbide stability or, indirectly, through microstructural influences on the formation of a protective oxide layer. For example, grain size, internal stresses, and dislocation structure can all influence the rate of carbon deposition. ${ }^{25}$ During the early stages of metal dusting, a heavily worked material can nucleate the metastable carbides sooner because of its higher density of dislocations. ${ }^{2}$ On the other hand, deformation can aid the development of a protective chromia layer under the appropriate environmental conditions; dislocations can serve as paths for chromium to diffuse to the alloy surface to react with oxygen to form a barrier layer of $\mathrm{Cr}_{2} \mathrm{O}_{3} \cdot{ }^{22}$ In this way, cold work can have a beneficial effect on resistance to metal dusting for alloys with sufficient chromium activity. For the same reasons, refining the grain size of a chromia-former (by deformation or other means) can also impart improved resistance to carburization and metal dusting by facilitating the formation of a $\mathrm{Cr}_{2} \mathrm{O}_{3}$ layer. 


$$
\text { , }
$$




\section{INFLUENCE OF SYSTEM OPERATING PARAMETERS ON CARBON DEPOSITION AND METAL DUSTING}

Coal gasification processes are typically targeted to the generation of a product gas containing a relatively high concentration of $\mathrm{CO}$. As discussed in Sect. 2, this high $\mathrm{CO}$ concentration essentially guarantees that a carbon activity greater than unity will be achieved on cooling the gas downstream of the gasifier reaction vessel. Calculations in Sect. 2 indicated that the prospects of drastically reducing the thermodynamic potential for carbon deposition by additions of $\mathrm{H}_{2} \mathrm{O}$ do not appear feasible, given the amounts of $\mathrm{H}_{2} \mathrm{O}$ that would be required. Hydrogen additions offer another approach for reducing the carbon activity on cooling, but this would involve a radical change in the gasification process or a separate source of $\mathrm{H}_{2}$. Furthermore, there is no assurance that the rate of the chemical reactions involving any of these additions (particularly $\mathrm{H}_{2}$ ) could compete kinetically with that of the $\mathrm{CO}$ decomposition reaction as the gas is cooled. Thus, the operating parameter variations that appear most effective for inhibiting carbon deposition are the $\mathrm{H}_{2} \mathrm{~S}$ and $\mathrm{NH}_{3}$ levels maintained in the product gas and the rate and degree of cooling between the gasifier and the gas turbine. The oxygen activity of the product gas is another operating parameter that may be important since it could be manipulated to maintain oxide films as carbon deposition barriers on metals otherwise susceptible to metal dusting. Alternatively, barrier surface oxides could be established by a preoxidation procedure, either by treating individual components before system assembly or by operating the gasifier in an oxidizing (combustion) mode prior to the start of gasification. However, long-term stability and integrity of such oxides may be problematical.

As discussed in Appendix A, instances of metal dusting have been reported in operating gasification systems. However, it appears that most gasifiers have not been plagued by serious metal dusting and deposition problems to date, particularly in contrast to many other chemical processes containing comparable $\mathrm{CO}$ concentrations. One probable reason is that the carbon activities in these systems are not sufficient to form $\mathrm{Fe}_{3} \mathrm{C}$ to the exclusion of oxides or sulfides of iron (see Sect. 2). In addition, the relatively high $\mathrm{H}_{2} \mathrm{~S}$ contents that generally exist in the product gas ahead of the filtration and sulfur removal systems should ensure that sufficient sulfur is available to inhibit carbon deposition or carbide formation over the most crucial temperature range during gas cooling. Once the gas is cooled by water quenching, carbon deposition would be appreciably slowed, with or without $\mathrm{H}_{2} \mathrm{~S}$. If the $\mathrm{H}_{2} \mathrm{~S}$ is the key to preventing carbon deposition, this problem would assume greater significance with the adoption of hot sulfur-removal processes in future gasifiers because the $\mathrm{H}_{2} \mathrm{~S}$ will then be removed in a temperature regime where carbon deposition and metal dusting are possible. The operating parameters that then would become critical are the temperatures of the hot-gas cleanup system and the downstream piping, and the level to which $\mathrm{H}_{2} \mathrm{~S}$ has been reduced in the gas flowing through these sections.

An approach for setting the $\mathrm{H}_{2} \mathrm{~S}$ content in gasifiers incorporating hot sulfur-removal systems would be to maintain an $\mathrm{H}_{2} \mathrm{~S}$ level that is sufficient to inhibit carbon deposition and metal dusting in piping sections ahead of the gas turbine but that is too low to compromise the corrosion resistance of the gas-containment material. Barnes et al. demonstrated that, for high-chromium $\mathrm{Fe}-\mathrm{Ni}-\mathrm{Cr}$ alloys at $1000^{\circ} \mathrm{C}\left(1830^{\circ} \mathrm{F}\right)$, at $\mathrm{H}_{2} \mathrm{~S}$ levels up to $100 \mathrm{ppm}$, sulfur adsorption on carbides formed on the alloy surface inhibited carbon pickup. ${ }^{32,33}$ Higher levels of $\mathrm{H}_{2} \mathrm{~S}$ also reduced internal carburization but promoted the formation of a surface layer of chromium sulfide, which led to increased corrosion. ${ }^{33}$ Whether such a critical range of $\mathrm{H}_{2} \mathrm{~S}$ exists for the present case cannot be determined on the basis of current information, but it becomes an important consideration in establishing the desired operating parameters for advanced gasifiers.

The $\mathrm{NH}_{3}$ concentration of the product gas is another operating parameter that is reported to affect the kinetics of carbon deposition and metal dusting. ${ }^{2}$ However, as discussed in Sect. $2, \mathrm{NH}_{3}$ is relatively unstable in the given product gas chemistry and may be relatively difficult to control. As in the case of $\mathrm{H}_{2} \mathrm{~S}$, the level of $\mathrm{NH}_{3}$ required to inhibit carbon deposition and metal dusting in gasifiers is unknown and would need to be evaluated experimentally. 
There appears to be no way to escape the temperature window for carbon deposition if the product gas is maintained at the exit temperature of a hot-gas cleanup system. However, cooling the gas immediately downstream from the cleanup system would afford a way of limiting any metal dusting concerns if a low-alloy steel is used as the connecting piping to the gas turbine. The gas temperature would need to be lowered to below about $400^{\circ} \mathrm{C}\left(750^{\circ} \mathrm{F}\right)$ to suppress any possibility of metal dusting of the low-alloy steel, assuming no other means of inhibition were employed. Disadvantages of this approach include the additional surface area of the heat exchanger and, in the case of integrated combined cycle units, a reduction in the gas turbine inlet temperature.

Steam additions are of limited value in inhibiting carbon deposition (see Sect. 2); however, by increasing the oxygen activity of the product gas, steam additions could improve the stability of oxide films ( $\mathrm{FeO}$ on iron or low-alloy steels; $\mathrm{Cr}_{2} \mathrm{O}_{3}, \mathrm{Al}_{2} \mathrm{O}_{3}$, or $\mathrm{SiO}_{2}$ on applicable alloys) that form on metals that otherwise might be susceptible to metal dusting. Steam additions would also decrease the temperature at which unit carbon activity is achieved in air-blown gasifiers (see Sect. 2). Such a temperature decrease could prove beneficial by allowing a gasifier to operate above the temperature window of metal dusting for certain materials. 


\section{MATERIAL SELECTION CONSIDERATIONS FOR HOT-GAS CLEANUP SECTIONS OF COAL GASIFICATION SYSTEMS}

Metallic materials will be used for many of the components of the hot-gas cleanup systems of gasifiers. These components include support plates, piping, and, possibly, the filters themselves. From the previous discussion, it is apparent that system deterioration by carbon deposition and the related alloy degradation by metal dusting are potential concerns associated with long-term operation of such systems, particularly if certain alloys are used. Ceramics such as alumina or those based on silicon are resistant to carbon-related degradation in the gasification environments. However, refractory liners containing iron can suffer from CO disintegration. ${ }^{9}$ Furthermore, although not highly likely, if catalytic species form part of the trapped char/ash particles on ceramic filters, they could lead to material degradation. Therefore, depending on the specific application, ceramic parts may or may not be immune from carbon-induced problems.

Based strictly on metal-dusting considerations, nickel-based or high-chromium alloys would be favored as materials for hot-gas cleanup components over carbon or low-alloy steels. ${ }^{2.3}$ However, nickel and alloys with high nickel concentrations can suffer from metal dusting, albeit at higher temperatures than iron-rich alloys (see Fig. 6). If oxidation conditions are such that continuous chromia scales can form, materials with substantial chromium concentrations are probably preferred because the oxide surface layer can provide true protection from degradation by carbon. Since the ability to reliably form the desired scale increases with increasing chromium availability, activity, and diffusivity, the commonly used austenitic stainless steels (with about $18 \% \mathrm{Cr}$ ) have been found to be marginal for this application in CO-containing gases. ${ }^{22}$ In this regard, ferritic stainless steels, such as type 446 , may be a better choice since they have relatively high chromium concentrations and higher chromium diffusivity.

As discussed previously, small concentrations of $\mathrm{H}_{2} \mathrm{~S}$ in the gasifier environment can significantly inhibit carbon and carbide formation and, therefore, metal dusting. However, even such small concentrations can still be sufficient to accelerate the corrosion of nickel-based alloys, steels, and other heat-resistant alloys at $600^{\circ} \mathrm{C}$ $\left(1110^{\circ} \mathrm{F}\right)$ and above. As discussed in Sect. 5, a balance between the concentration of sulfur needed for inhibition and that which causes significant degradation by mixed-gas corrosion would be required. Obviously, the use of sulfidation-resistant alloys would allow greater freedom in limiting sulfur pressures in the gasifier environment. Iron-aluminide alloys offer some promise for use in hot-gas cleanup systems as they offer excellent sulfidation resistance in reducing environments with relatively high $\mathrm{H}_{2} \mathrm{~S}$ contents. ${ }^{34}$ However, metal dusting of iron aluminides may be possible. ${ }^{31}$ The formation of an alumina scale imparts sulfidation resistance to iron aluminides and should also be a barrier to metal dusting. Therefore, if preoxidized, iron aluminides should be more resistant to degradation by both carbon and sulfur, but this remains to be demonstrated. Nickel aluminides should be preferable to iron aluminides as alumina-forming alloys for metal-dusting resistance because nickel is less reactive in the product gas environment, although it can exhibit a type of metal dusting in which a Ni-C solid solution decomposes directly without formation of an intermediate carbide. ${ }^{35}$ Nickel aluminides would not be suitable in the presence of $\mathrm{H}_{2} \mathrm{~S}$ because they are very susceptible to sulfur-accelerated corrosion (see, for example, ref. 36).

For materials that need to rely on a surface oxide of aluminum, chromium, or silicon for protection from metal dusting, any microstructural or compositional modifications that improve the adhesion, soundness, mechanical integrity, and erosion resistance of these layers will improve their performance in the hot-gas cleanup system of gasifiers. Mechanically worked, pore-free metal surfaces increase the ability to form adherent, protective scales relative to as-cast, rough surfaces or those retaining mill scale. Honed tubes have shown improved lifetimes compared with as-spun-cast tubes in some environments subject to carbon deposition. ${ }^{37}$ The factors controlling such properties of oxide scales are not all known and form the subject of many present investigations. However, the ability to improve scale adhesion by addition of small amounts of certain reactive elements or oxides has long been recognized. ${ }^{38}$ Any choice of materials that form alumina; chromia, or silica should be governed, in part, by whether these alloys have been optimized for scale adhesion 
and integrity. The use of materials that form such protective scales presupposes that they are stable in the gasifier environment. System modification to allow the growth of protective oxide films by selective oxidation during steam injection could also enhance oxide scale formation, as discussed in Sect. 5.

Materials selection is rarely based on corrosion performance alone. Cost considerations often preclude the use of the higher-alloyed materials or advanced ceramics. The relatively low costs of carbon and low-alloy steels make them the materials of choice for most power-generation systems in order to show an acceptable retum on investment. However, the potential susceptibility of these materials to carbon deposition and metal dusting must be addressed in light of long-term operation of hot-gas cleanup systems of coal gasifiers. If the currently targeted $\mathrm{H}_{2} \mathrm{~S}$ contents can be achieved by hot-gas desulfurization, the increased potential for carbon-related material degradation will almost certainly impact gasifier design and operating conditions. Modifications such as lowering the exposure temperature, introducing a gas-phase inhibitor, and/or using surface protection (coatings, claddings, or liners) may be required. The surface protection approach may be required for accommodating off-normal conditions occurring in a system that has been designed to minimize carbon formation and dusting solely by process control. The choice of coatings, claddings, or liners would be governed by the same materials considerations discussed immediately above. For example, steels could be chromized, chromized/siliconized, or aluminized to facilitate formation of protective surface oxides. Ducts could be lined with a material resistant to corrosion by the carbon-containing environment or fabricated from co-extruded tubing that incorporates an appropriate surface in contact with the product gas. 


\section{RECOMMENDATIONS FOR FURTHER EVALUATION OF POSSIBLE DEGRADATION MODES}

There are a number of ways to examine various operating and environmental conditions in which carbon deposition and metal dusting might be expected in the product gas streams of coal gasification processes. An initial approach is by use of thermodynamic predictions: as demonstrated in Sect. 2, knowledge of appropriate reactions and free energies is used to calculate carbon activities and phase stabilities and therefore to determine if a driving force for carbon deposition and metal dusting exists for a given gas mixture as a function of temperature and pressure. However, because other factors (such as kinetics, effects of inhibitors, and particular material conditions) can override thermodynamic considerations related to these phenomena, such predictions must then be experimentally verified. Based on this assessment, the empirical evaluation of the ability of equilibrium thermodynamics and accompanying assumptions on relative reaction kinetics to accurately predict carbon-related degradation tendencies should form the most important part of any relevant test program. The thermochemical calculations described in Sect. 2 unequivocally predict, in the absence of inhibitors, carbon deposition in certain temperature ranges for all of the examined gasifiers. More importantly, it was shown that $\mathrm{Fe}_{3} \mathrm{C}$, a necessary precursor to metal-dusting damage of steels, can become stable in these gasifier environments when carbon deposition and $\mathrm{CH}_{4}$ formation are sluggish, as they may well be in many gasifier systems. It is therefore important to determine experimentally the temperature and environmental conditions under which $\mathrm{Fe}_{3} \mathrm{C}$ can form and lead to degradation of the steel. The necessary steps in such a process include (1) specification of a representative gas composition, specifically one in which $\mathrm{Fe}_{3} \mathrm{C}$ is predicted to be stable over a certain temperature range and under appropriate kinetic conditions, (2) exposure of a susceptible material in these environments, and (3) postexposure analysis to correlate the occurrence of carbon deposition and metal dusting with the different environmental conditions. In a similar manner, an experimental validation approach can be taken with respect to verifying the effects of $\mathrm{H}_{2} \mathrm{~S}$ and steam injection on carbon deposition and $\mathrm{Fe}_{3} \mathrm{C}$ stability. These types of experiments would help resolve the questions associated with (admittedly limited) observations that operating experience with coal gasification plants to date has not indicated significant problems with carbon-related degradation (Appendix A).

The above tests (designated Type I for convenience) are designed to evaluate whether certain environmental conditions relevant to operating gasifiers can lead to (or prevent) metal dusting. By combining assumptions regarding reaction kinetics with thermochemical calculations, predictions can be formulated and then compared with experimental results. Such tests would evaluate certain factors that can counter thermodynamic tendencies in determining whether carbon deposition and metal dusting will occur. A complementary approach would be to investigate relative materials susceptibility to metal dusting. In this case, using a given gasifier-relevant environment that is known to cause metal dusting of a low-alloy steel (which serves as a baseline), exposures of various compositions and surface treatments (such as conferred by preoxidation treatments) would be conducted and compared. Such experiments (Type II) could also be used to investigate sulfidation tendencies of different materials, and when combined with Type I tests, to determine critical levels of $\mathrm{H}_{2} \mathrm{~S}$ necessary to suppress metal dusting and avoid degradation by metal sulfide formation.

Experimental methods to evaluate carbon-related degradation phenomena can be broadly categorized into four types: (1) surface reaction studies, (2) laboratory corrosion exposures, (3) rig tests, and (4) test beds. Surface studies involving sensitive analytical probes of composition and structure can be used to investigate catalytic effects and to understand the effects of inhibitors on the carbon deposition process and the effectiveness of potential barrier layers. Laboratory corrosion exposures involve small-scale studies of candidate materials in simulated gas environments. ${ }^{3,17,30}$ Analyses are done by following the weight change of coupons, often in a microbalance, and posttest destructive examination and analysis of the specimens. Such tests are useful for determining the susceptibility of a particular material to carbon-related phenomena for a given set of environmental and temperature conditions (including the effects of inhibitors). They can be used to establish the temperature window of susceptibility to metal dusting for given gas compositions and material 
compositions. ${ }^{1,2}$ They are appropriate for the Type II experiments. Rig tests are somewhat more complex. Simulated gases at appropriate velocities flow through tubes of candidate materials. ${ }^{19,29}$ Carbon buildup on tube walls can be monitored, and coupons can be exposed and removed at various times for metallurgical and chemical examination. Rig tests are again useful for qualitatively judging the susceptibility of materials as well as for examining the effect of temperature, and could be used for Type II tests. The use of flowing gases allows an erosion component to be included. Test beds connected to actual gasification reactors (such as those at the Federal Energy Technology Center in Morgantown, West Virginia) offer the most realistic experimental conditions outside of operating plants. Such facilities can be used to verify results from laboratory and rig tests and to qualify materials and certain process modifications being considered for new or operating plants. As such, they may be the best approach for Type I tests, particularly if the results are to be used for guidance related to system design or operating parameters.

On the basis of the present work, specific recommendations regarding needed evaluation of possible carbon-related degradation modes are enumerated as follows in order of priority.

1. Experimental validation (Type I) tests should be conducted with a candidate low-alloy steel using variants of a specific gasifier environment in a manner described above. The objective of such a project would be to determine the operating conditions, if any, under which $\mathrm{Fe}_{3} \mathrm{C}$ can form and can lead to metal dusting. Such experiments are probably best conducted using a test bed.

2. Type I tests with the candidate low-alloy steel should be used to investigate the effects of a wide range of $\mathrm{H}_{2} \mathrm{~S}$ levels on carbon deposition and $\mathrm{Fe}_{3} \mathrm{C}$ stability. While this study could be part of recommendation 1 , these experiments would be specifically targeted at examining the ramifications associated with hot-gas cleaning on materials degradation in the gas-delivery system. With appropriate design, such tests can also be used to determine optimal $\mathrm{H}_{2} \mathrm{~S}$ levels necessary to avoid carbon-related degradation and sulfidation problems. This investigation could be conducted at the laboratory level.

3. The Type II approach should be used to investigate surface treatments for mitigation of metal dusting, particularly with respect to the stability and long-term reliability of chromia, silica, and alumina scales. These results would have particular relevance to operating procedures that rely on a preoxidation treatment to establish protective oxide layers. Laboratory corrosion exposures would be the preferred method of experimentation. Rig tests or the use of test beds could then be used to qualify specific preoxidation treatments.

4. Given the lack of substantial data on the metal-dusting performance of alumina-forming alloys, a set of Type II laboratory-level experiments incorporating such materials would be beneficial. In particular, the metal-dusting susceptibility of iron aluminides should be explored in greater detail as its excellent sulfidation resistance would allow it to be used in gases with higher $\mathrm{H}_{2} \mathrm{~S}$ levels (see recommendation 2). 


\section{SUMMARY AND CONCLUSIONS}

The objectives of this report were to establish the potential risk of operating problems due to carbon deposition and metal dusting in advanced coal-gasification processes and to identify mitigation methods. Metal dusting is a pernicious form of degradation, primarily of iron, cobalt, and nickel. In metal dusting, the metal, or alternatively, a metal compound, functions as a catalyst for the disproportionation of $\mathrm{CO}$ when carbon activities exceed unity. Under the appropriate environmental and material conditions, the end result is a breaking up of the metal structure to create powdery carbon and fine particles (thus the term "metal dusting"). The results of the present effort may be summarized as follows:

1. A review of the literature relating to carbon deposition and metal dusting was conducted. Key sources of information were from research on (a) metal dusting, (b) $\mathrm{CO}$ disintegration of refractories; and (c) carbon deposition, including formation of filamentous carbon. Although the literature in each of these areas proved very useful for this review, cross-referencing among the three appeared incidental, at best.

2. The product gas compositions of eight representative gasifier systems were examined with respect to the carbon activity of the gases at temperatures ranging from 480 to $1090^{\circ} \mathrm{C}\left(900\right.$ to $2000^{\circ} \mathrm{F}$ ). The composition of the product gas, in particular the $\mathrm{CO}$ concentration from the gasification processes considered, is such that carbon deposition is essentially guaranteed when the gas is cooled after exiting the gasifier. Assuming that all of the gas components are in thermodynamic equilibrium, calculations show that carbon activities greater than unity would result at temperatures below 800 to $870^{\circ} \mathrm{C}(1470$ to $1600^{\circ} \mathrm{F}$ ) in the case of air-blown gasifiers and at considerably higher temperatures in the case of oxygen-blown gasifiers containing greater than 54 vol \% CO.

3. Phase stability calculations indicate that $\mathrm{Fe}_{3} \mathrm{C}$ is only stable under very limited thermodynamic and kinetic conditions and that $\mathrm{FeO}$ and $\mathrm{Fe}_{0.877} \mathrm{~S}$ tend to form instead of the carbide. As formation of $\mathrm{Fe}_{3} \mathrm{C}$ is a necessary step in the metal dusting of steels, there are numerous gasifier environments where this type of carbon-related degradation will not occur, particularly under conditions associated with higher oxygen and sulfur activities. These calculations also indicated that the removal of $\mathrm{H}_{2} \mathrm{~S}$ by a hot-gas cleanup system may have less effect on the formation of $\mathrm{Fe}_{3} \mathrm{C}$ in air-blown gasifier environments, where the iron oxide phase can exist and is unaffected by the removal of sulfur, than in other gasification systems where iron sulfide provides the only potential barrier to $\mathrm{Fe}_{3} \mathrm{C}$ formation.

4. In current gasification systems, significant problems resulting from carbon deposition have not been experienced, or, if they have, they have not been reported. The main factors militating against carbon deposition and/or metal dusting in these systems are thought to be (a) the presence of sufficient sulfur in the raw gas leaving the gasifier to inhibit the relevant reactions by poisoning catalytic surfaces; (b) rapid cooling of the product gas, which reduces the residence time of the gas at temperatures at which carbon deposition is favored; and (c) the gas compositions being outside the range of thermodynamic stability of $\mathrm{Fe}_{3} \mathrm{C}$.

5. The adoption of hot-gas desulfurization strategies will probably increase the significance of the carbon-related degradation, since $\mathrm{H}_{2} \mathrm{~S}$ will then be removed in a temperature regime where carbon deposition and metal dusting are possible.

6. Alloy selection can be an important consideration relative to process performance and economics. With respect to prevention of carbon deposition and metal dusting, alloy selection is reduced to two general alternatives: carbon or low-alloy steels, provided certain criteria are met (see no. 7 below), and higher- 
alloyed steels or heat-resistant alloys. As stated in conclusion (2), temperatures prevailing in gasifiers employing hot-gas cleanup essentially guarantee conditions that will support carbon deposition on carbonand low-alloy steels. Metal dusting is then possible when a metastable carbide (normally $\mathrm{Fe}_{3} \mathrm{C}$ ) can form and then decompose.

7. The use of carbon steels and/or low-alloy steels will dictate that the process gas composition be such that $\mathrm{Fe}_{3} \mathrm{C}$ cannot form if the potential for metal dusting is to be eliminated. Alternatively, process modifications could include reintroducing hydrogen sulfide (to poison the carbon deposition reaction or to form iron sulfide at the expense of $\left.\mathrm{Fe}_{3} \mathrm{C}\right)$, quenching the gas to perhaps as low as $400^{\circ} \mathrm{C}\left(750^{\circ} \mathrm{F}\right)$, and/or injecting steam.

8. If higher-alloy steels (those that form and maintain a protective chromia film on the surface) are used, a hydrogen sulfide-free gas (or a gas with very low hydrogen sulfide content at higher temperatures) may be processed without concern about carbon deposition and metal dusting.

9. It is considered prudent to conduct some testing, preferably under prototypical coal gasification conditions, to experimentally validate the thermodynamic calculations and assumptions about kinetic limitations that are key to developing a predictive capability with respect to carbon formation and metal dusting. 


\section{REFERENCES}

1. R. F. Hochman and J. H. Burson III, "The Fundamentals of Metal Dusting," API Division of Refining Proc. 46, 331-44 (1966).

2. R. F. Hochman, "Catastrophic Deterioration of High Temperature Alloys in Carbonaceous Atmospheres," pp. 715-32 in Proc. Electrochem. Soc. 77-1 (1976).

3. J. C. Nava Paz and H. J. Grabke, "Metal Dusting," Oxid. Met. 39, 437-56 (1993).

4. H. J. Grabke, R. Krajak, and J. C. Nava Paz, "On the Mechanism of Catastrophic Carburization: Metal Dusting," Corros. Sci. 35, 1141-50 (1993).

5. R. A. Perkins, "Carburization of High-Temperature Alloys," pp. 617-47 in Behaviour of High-Temperature Alloys in Aggressive Environments, ed. I. Kirman, J. B. Marriott, M. Merz, P. R. Sahm, and D. P. Whittle, The Metals Society, London, 1980.

6. J. K. Stanley, "Carburization of Stainless Steels in Methane-Hydrogen," pp. 143-54 in High Temp. Gas-Met. React. Mixed Environ., ed. S. A. Jansson and Z. A. Foroulis, AIME, New York, 1973.

7. H. J. Grabke and I. Wolf, "Carburization and Oxidation," Mater. Sci. Eng. 87, 23-33 (1987).

8. R. T. K. Baker, D. J. C. Yates, and J. A. Dumesic, "Filamentous Carbon Formation over Iron Surfaces," pp. 1-22 in Coke Formation on Metal Surfaces, ed. L. F. Albright and R. T. K. Baker, American Chemical Society, 1982.

9. J. J. Brown, Jr., Investigation of Carbon Monoxide Disintegration of Refractories in Coal Gasifiers, Virginia Polytechnic Institute and State University report, VPI/ME-13702-12, July 1984.

10. T. M. Besmann, SOLGASMIX-PV, A Computer Program To Calculate Equilibrium Relationship in Complex Chemical Systems, ORNL/TM-5775, Oak Ridge Natl. Lab., April 1977.

11. P. Kofstad, High Temperature Corrosion, Elsevier Applied Science, London, 1988, pp. 428-29.

12. P. L. Walker, Jr., J. F. Rakszawski, and G. R. Imperial, "Carbon Formation Over Iron Catalysts: I. Properties of Iron Formed," J. Phys. Chem. 63, 133-39 (1959).

13. A. Sacco, Jr., and J. C. Caulmare, "Growth and Initiation Mechanism of Filamentous Coke," pp. 177-92 in Coke Formation on Metal Surfaces, ed. L. F. Albright and R. T. K. Baker, American Chemical Society, 1982.

14. P. A. Lefrancois and W. B. Hoyt, "Chemical Thermodynamics of High Temperature Reactions in Metal Dusting Corrosion," Corrosion 19, 360t-368t (1963).

15. T. Kalina and J. A. Kivlen, "Process of Reducing Iron Oxide Ores with Gases Containing Carbon Monoxide," U. S. Patent 3,377,156, April 1968. 
16. M. J. Bennett, G. H. Chaffey, B. L. Myatt, and D. R. V. Silvester, "Inhibition by Sulfur Poisoning of the Heterogeneous Decomposition of Acetone," pp. 223-38 in Coke Formation on Metal Surfaces, ed. L. F. Albright and R. T. K. Baker, American Chemical Society, 1982.

17. H. J. Grabke, C. B. Bracho-Troconis, and E. M. Mueller-Lorenz, "Metal Dusting of Low Alloy Steels," Werkst. Korros. 45, 215-21 (1994).

18. T. F. Berry, R. N. Ames, and R. B. Snow, "Influence of Impurities and Role of Iron Carbides in Deposition of Carbon from Carbon Monoxide," J. Amer. Ceram. Soc. 39, 308-18 (1956).

19. E. Q. Camp, C. Phillips, and L. Gross, "Corrosion of 18-8 Alloy Furnace Tubes in High-Temperature Vapor Phase Cracking Service," Corrosion 1, 149-60 (1945).

20. H. J. Grabke, "Metal Dusting of Low and High Alloy Steels," Corrosion 51, 711-20 (1995).

21. V. Krebs, J. F. Mareche, G. Furdin, and D. Dumay, "Contribution to the Study of Carbon Deposition in Coke Ovens," Fuel 73, 1904-10 (1994).

22. H. J. Grabke, R. Krajak, and E. M. Mueller-Lorenz, "Metal Dusting of High- Temperature Alloys," Werkst. Korros. 44, 89-97 (1993).

23. D. E. Brown, J. T. K. Clark, A. I. Foster, J. J. McCarroll, and M. L. Sims, "Inhibition of Coke Formation in Ethylene Steam Cracking," pp. 23-44 in Coke Formation on Metal Surfaces, ed. L. F. Albright and R. T. K. Baker, American Chemical Society, 1982.

24. W. R. Ruston, M. Warzee, J. Hennaut, and J. Waty, "The Solid Reaction Product of the Catalytic Decomposition of Carbon Monoxide on Iron at $550^{\circ} \mathrm{C}$," Carbon 7, 47-57 (1969).

25. F. W. A. Geurts, R. G. Cnossen, A. Sacco, Jr., and R. R. Biederman, "Carbon Deposition over Transition Metal Alloys-II. Kinetics of Deposition over $<\mathrm{FeNi}>$ and $<\mathrm{FeCo}>$ Alloy Foils," Carbon 32, 1151-69 (1994).

26. Y. Inokuti, "Formation of Graphite on the Surface of Cold Rolled Low Carbon Steel Sheet During Annealing," Trans. ISIJ 15, 314-23 (1975).

27. R. A. Perkins, W. C. Coons, and F. J. Radd, "Metal Dusting Corrosion in Coal Gasification Environments," pp. 733-49 in Proc. Electrochem. Soc. 77-1 (1976).

28. I. Koszman, "Factors Affecting Catastrophic Carburization Metal Dusting," pp. 155-67 in High Temp. Gas-Met. React. Mixed Environ., ed. S. A. Jansson and Z. A. Foroulis, AIME, New York, 1973.

29. L. H. Wolfe, "Laboratory Investigations of High Temperature Alloy Corrosion and Failures," Mater. Perform. 17, 38-44 (1978).

30. R. F. Hochman, "Metal Deterioration in Carbon Monoxide and Hydrocarbon at Elevated Temperatures," pp. 119-33 in Proc. Third Int'l. Congress on Metallic Corrosion, Vol. IV, 1969. 
31. G. H. Meier, N. Birks, F. S. Pettit, R. A. Perkins, and H. J. Grabke, "Environmental Behavior of Intermetallic Materials," pp. 861-77 in Structural Intermetallics, ed. R. Darolia, J. J. Lewandowski, C. T. Liu, P. L. Martin, D. B. Miracle, and M. V. Nathal, TMS, Warrendale, Pa, 1993.

32. J. Barnes, J. Corish, E. Franck, and J. F. Norton, "Influence of Sulfur on the Nature and Morphology of Carbides Formed on the Surfaces of Fe-Ni-Cr Alloys at High Temperatures," Oxid. Met. 24, 85-97 (1985).

33. J. Barnes, J. Corish, and J. F. Norton, "Sulfur Effects on the Internal Carburization of Fe-Ni-Cr Alloys," Oxid. Met. 26, 333-50 (1986).

34. J. H. DeVan and P. F. Tortorelli, "Oxidation/Sulfidation of Iron-Aluminum Alloys," Mater. at High Temp. 11, 30-35 (1993).

35. D. Monceau, E. M. Müller-Lorenz, and H. J. Grabke, "Metal Dusting of Stainless Steels," to be published in Mater. Sci. Forum, 1996.

36. U. Brill, "High-Temperature Corrosion of $\mathrm{Ni}_{3} \mathrm{Al}$ Intermetallic Phase Materials," Werkst. Korros. 41, 682-88 (1990).

37. D. B. Roach, Battelle Columbus Laboratories, unpublished results, 1974.

38. D. P. Moon, "Role of Reactive Elements in Alloy Protection," Mater. Sci. and Technol. 5, 754-764 (1989). 


\section{APPENDIX A \\ INDICATIONS OF METAL DUSTING IN OPERATING COAL GASIFICATION PLANTS}

\section{A.1. Shell Internationale Petroleum Maatschappij B.V.}

Shell advised that they are aware of the phenomenon of metal dusting. In fact, Shell has focused a significant R\&D effort into understanding this phenomenon since their hydrocarbon gasification/partial oxidation processes produce high carbon activity regimes. According to Shell, they have observed only a very few cases of metal dusting. By examination of the differences between process conditions along with the results of the Shell R\&D, they identified the cause of the metal dusting and devised a mitigation technique. The specifics of the mitigation technique are proprietary, and the technique is not available for licensing.

\section{A.2. British Coal Corporation Coal Technology Development Division}

The Coal Technology Development (CTD) Division advised that they had experienced a possible example of metal dusting of aluminized type 310 stainless steel approximately ten years ago in a coal gasification test. Metal dusting is not considered, by CTD, to be a problem in actual coal gasification systems. Carbon deposition occurs in tests, even though hydrogen sulfide is present throughout the process. The extent of carbon deposition is alloy specific. Carbon dumping is also observed on ceramics, which raises the obvious concern of filter plugging for high-temperature filtration using ceramics.

\section{A.3. British Gas plc}

The British Gas experience is that metal dusting is not a problem in their gasification systems. British Gas advised that a form of metal dusting referred to as "green rot" was experienced with nickel-base alloys in processes developed by Imperial Chemical Industries (ICD). According to British Gas, a solution to this problem was identified by ICI. 